\title{
Review Article \\ Occupational Therapy's Unique Contribution to Chronic Pain Management: A Scoping Review
}

\author{
Émilie Lagueux $\left(\mathbb{D},{ }^{1,2}\right.$ Andréa Dépelteau, ${ }^{2}$ and Julie Masse ${ }^{3}$ \\ ${ }^{1}$ Research Center of the Centre Hospitalier Universitaire de Sherbrooke, Sherbrooke, Québec, Canada \\ ${ }^{2}$ Faculty of Medicine and Health Sciences, School of Rehabilitation, Université de Sherbrooke, Sherbrooke, Québec, Canada \\ ${ }^{3}$ Faculty of Medicine, School of Rehabilitation, Université de Montréal, Montréal, Québec, Canada
}

Correspondence should be addressed to Émilie Lagueux; emilie.lagueux@usherbrooke.ca

Received 9 July 2018; Accepted 17 September 2018; Published 12 November 2018

Academic Editor: Jacob Ablin

Copyright (c) 2018 Émilie Lagueux et al. This is an open access article distributed under the Creative Commons Attribution License, which permits unrestricted use, distribution, and reproduction in any medium, provided the original work is properly cited.

\begin{abstract}
Occupational therapy (OT) makes a unique contribution to chronic pain (CP) management due to its overarching focus on occupation. The aim of this scoping review was to describe current knowledge about this contribution by documenting OT roles, models, assessments, and intervention methods used with adults living with CP. A systematic search exploring 10 databases and gray literature from 2006 to 2017 was conducted. Fifty-two sources were retained and analysed. Results bring forward the main role of OT being improving activities and participation (76.9\%), the Canadian Model of Occupational Performance (9.6\%), and the Canadian Occupational Performance Measure (21.2\%). Within the 30 reported interventions, $73.3 \%$ related directly to the person, 20\% pertained to occupation (activities and participation), and 6.7\% addressed environmental factors. The distinction and complementarity between the bottom-up and the top-down approaches to OT intervention were discussed. This review highlights OT specificity in adult CP management.
\end{abstract}

\section{Introduction}

The World Health Organization (WHO) recognizes chronic pain $(\mathrm{CP})$ as a public health problem throughout the world. More than a symptom, $\mathrm{CP}$ is recognized as a disease in the International Classification of Diseases [1]. A recent systematic review estimated that the prevalence of $\mathrm{CP}$ worldwide was $30.3 \%$ for the global population [2]. The experience of pain interferes with different aspects of an individual's life [3], limiting their involvement in activities of daily living and their health-related quality of life [3]. Reid et al. [4] reported in a systematic review that interference with functioning and well-being are significantly associated with increasing pain severity $(p \leq 0.001)$. In fact, according to the International Association for the Study of Pain (IASP), one-third of people suffering from $\mathrm{CP}$ are unable or less able to maintain an independent and meaningful lifestyle due to their pain [5].

Being involved in meaningful life situations is a determinant of health and well-being and is itself an effective therapy [6]. According to these authors, occupation is everything people do to occupy themselves, including looking after themselves (self-care), enjoying life (leisure), and contributing to the social and economic fabric of their communities (productivity). Actually, the various definitions of occupation show some similarities with the concept of participation $[7,8]$ which refer more broadly to activities essential to survival as well as activities and roles necessary for well-being [7]. Furthermore, the International Classification of Functioning, Disability, and Health (ICF) [9] provides a common and shared understanding of functioning as well as a language that is multidisciplinary [10] and uses "disability" as an umbrella term which includes impairments (in body structures and functions), activity limitations, and participation restrictions [9]. Through their overarching focus on occupational performance and occupational engagement, occupational therapists make a unique contribution to pain prevention and management programs [11]. 
Enabling occupation is the ultimate goal of the OT clinical process. Occupational therapists provide a wide range of pain management interventions across the domains of physical, emotional, and spiritual occupational performance and have the knowledge, skills, and expertise to address CP management in all its complexity at individual clients and community and policy levels [11]. Occupational therapists' core skill, analyzing and adapting the physical, emotional, cognitive, and social demands of activities and occupations, allows them to identify and intervene on barriers to participate in specific life situations while considering environmental and personal factors [12-15].

Moreover, studies which describe the OT approach provide a deep understanding of the links between CP and occupation $[16,17]$ and suggest that engaging in occupation has the potential to mediate the pain experience and to alter biological, psychological, and social factors that are known to influence the pain experience $[18,19]$. In addition to addressing the disruptions in occupational performance caused by CP $[19,20]$, occupational therapists are concerned with the occupational identity $[12,21]$ of their client. The Model of Human Occupation [22] states that "occupational identity" constitutes the values, beliefs, roles, and interests which drive a person to perform daily activities [12]. Indeed, occupational therapists recognize that CP affects all areas of a client's life and their competency and identity, and they are trained to use a holistic approach to address the occupational needs of clients living with this problem $[12,13,21]$.

In spite of OTs theoretical foundations, many occupational therapists face challenges in defining and deploying their role in CP management. There appears to be a lack of a clear understanding by health professionals regarding the contribution of OT services with CP clients $[18,20]$. Of further concern is the findings of Robinson et al. [19] who noticed and warned that occupational therapists tend to use inappropriate evidence in working with people with CP and rely too much on evidence developed in other disciplines such as psychology. For instance, they report that occupational therapists have added mindfulness-based approaches to their practice without critically addressing the contribution of this approach in enabling occupational performance and ultimately participation in life situations. Skjutar et al. [20] conclude that two actions are necessary to ensure the growth and development of OT services for clients with CP: (i) researchers must develop evidence of effectiveness on occupation-based outcomes and (ii) clinicians need to develop expertise in evidence-based practice.

More recently, Hesselstrand et al. [23] published a systematic review that assessed the quality of studies describing and evaluating the effects of OT intervention in adults experiencing $\mathrm{CP}$. The main clinical recommendations arising from this review were that (i) OT interventions should start from the identified needs of the client with $\mathrm{CP}$, (ii) no support exists for the effectiveness of electromyographic biofeedback training as a supplement, and (iii) efficacy of instructions on body mechanics was significant during work-hardening treatment. These recommendations can be misleading to health professionals as they are not specific to
OT outcomes in CP which should endorse occupational engagement and participation.

To our knowledge, besides Hesselstrand et al. [23], no recent comprehensive review of OT practice in $\mathrm{CP}$ management is published. The purpose of the present review was to provide an overview of the current state of knowledge about the OT roles, models, assessments, and interventions methods used with adults living with CP.

\section{Methods}

Research in the field of rehabilitation tends to involve diverse methodological approaches and relies on both quantitative and qualitative data [24]. This heterogeneity and the widely dispersed publication of rehabilitation evidences pose substantial challenges for knowledge synthesis in rehabilitation [24]. A scoping review is a specific type of literature review involving rigorous and transparent methods for data collection, analysis, and interpretation [25]. This structured approach suits various research questions and facilitates gathering information from different sources, such as scientific literature and gray literature, as well as different study designs [26, 27]. Furthermore, scoping reviews aim to examine broad knowledge areas in order to identify gaps in the available scientific evidences; clarify key concepts; and report on relevant studies addressing and informing practice on a topic area [28]. Considering the need for a better understanding of the state of knowledge about OT for CP management in adults, a scoping review in the literature published between 2006 and 2017 was conducted according to the Arksey and O'Malley's framework [27] enhanced by the work of Levac et al. [26].

According to these authors, stage 1 involves identifying the research question. For this study, the main question was, "What is the current state of knowledge about OT for CP management in adults?" Three underlying questions based on the scientific literature contributed to documenting the OT process: (i) "What is the role of an occupational therapist for CP management in adults?" (ii) "Which assessment methods are available for use by the occupational therapist in CP management in adults?" (iii) "Which interventions support the OT intervention in CP management in adults?" The Canadian Practice Process Framework (CPPF) [6] formed the conceptual foundation for reporting the results.

Stage 2 involves identifying relevant studies. The scientific literature was searched through the following databases: Academic Search complete, CINAHL, Evidence-based medicine, Psychology and behavioral science collection, PsycINFO, PubMed, Scopus (MEDLINE and Embase), and OTseeker. The gray literature was searched through ProQuest for thesis and dissertations, and the Library University website was searched for books. Searching strategies were developed and adapted to the various databases as required in collaboration with an experienced librarian. The details of the search strategy used are given in Table 1.

Stages 3 and 4 involve an iterative team approach to selecting studies and charting data. To be included, articles had to meet all the following criteria: (i) document OT roles/assessments/interventions; (ii) focus on CP according 
TABle 1: Database Search strategy.

Database
Academic search complete, CINALH, evidence-based
medicine, psychology and behavioral science
collection, PsycINFO, and Scopus (MEDLINE and
Embase)

Embase)
Search strategy

(Occupational therapy: "Occupational therap*"/) AND (chronic pain related terms: "Chronic pain*" OR fibromyalgia* OR "back pain*" OR "long term pain*" OR migraine* OR "cervical pain*” OR "neck pain*" OR "complex regional pain syndrome" OR

"chronic musculoskeletal* pain*" OR "chronic

headache*” OR "chronic orofacial* pain*” OR

"chronic neuropathic* pain*") AND (practice related terms: Intervention* OR evaluat* OR assess* OR role* OR manag*)

(Occupational therapy: Occupational therapy OR occupational therapist OR occupational therapies OR occupational therapists) AND (chronic pain related terms: "Chronic pain" OR "chronic pains" OR fibromyalgia OR fibromyalgias OR "back pain” OR "back pains" OR migraine OR migraines OR "cervical pain" OR "cervical pains" OR "neck pain" OR "neck pains" OR "complex regional pain syndrome" OR

"chronic musculoskeletal pain" OR "chronic musculoskeletal pains" OR "chronic headache" OR

"chronic headaches" OR "chronic orofacial pain" OR

"chronic orofacial pains" OR "chronic neuropathic pain" OR "chronic neuropathic pains") AND (practice related terms: Intervention $\mathrm{OR}$ interventions OR evaluate OR evaluation OR evaluations OR assess OR assessment OR role OR roles OR manage OR management)

(Practice related terms: Assess* OR role* OR manag* OR evaluat* OR intervention* AND "chronic pain*") to the WHO International Classification of Diseases (chronic primary pain, chronic posttraumatic and postsurgical pain, chronic neuropathic pain, chronic headache and orofacial pain, chronic visceral pain, and chronic musculoskeletal pain) [1]; (iii) address an adult population (18-65 years old); (iv) be published between 2006 and 2017; and (v) be written in English or French. Sources were excluded if they addressed cancer pain, hand therapy, and chronic diseases, and discussed only interdisciplinary or multidisciplinary approaches in CP management, without any specification about OT practice.

A total of 524 sources were identified through searching databases (53 from Academic Search complete, 60 from CINAHL, 12 from Evidence-based medicine, 9 from Psychology and behavioral science collection, 47 from PsycINFO, 94 from PubMed, and 243 from Scopus (MEDLINE and Embase, and 6 from OTseeker), and also 9 sources from potentially relevant gray literature were identified. Independently, two members of the research team (first and second authors) read each title/abstract and judged whether they were relevant to the research question and inclusion criteria or not. When a disagreement arose between the two reviewers, the third member of the research team (last author) offered additional consultation until a decision was reached. If the relevance of a study was still unclear, then the full article was read. Thus, 92 of the 533 sources were retained for full-text review. All 92 sources were reviewed by one member of the research team (second author) and independently validated by one researcher (first author). Hence, the three authors agreed on removing 40 sources considered irrelevant for the purpose of the study. Consequently, 52 sources were retained for data extraction. Two reviewers (second and last authors) extracted relevant information from these 52 sources, which were subsequently validated by the first author (first author). A flowchart of the source selection process for each stage of the review is presented in Figure 1.

The review team developed a data extraction process by analyzing three studies to ensure the presence of all relevant information. Charting the results was an iterative process whereby the charting table was continually updated [28]. This process leads to the addition of a category related to the models/conceptual frameworks used by the author(s). The final data chart included (i) author(s); (ii) year of publication; (iii) country of origin; (iv) type of publication; (v) aim/purpose; (vi) study population and sample size (if applicable); (vii) role of the occupational therapist; (viii) models/conceptual frameworks; (ix) OT assessment methods; and (x) OT interventions methods.

Stage 5 involves collating, summarizing, and reporting results. In the present case, qualitative thematic content analysis [29] was performed to describe OT practice for CP management in adults regarding roles, models/conceptual frameworks, assessment, and interventions methods. 


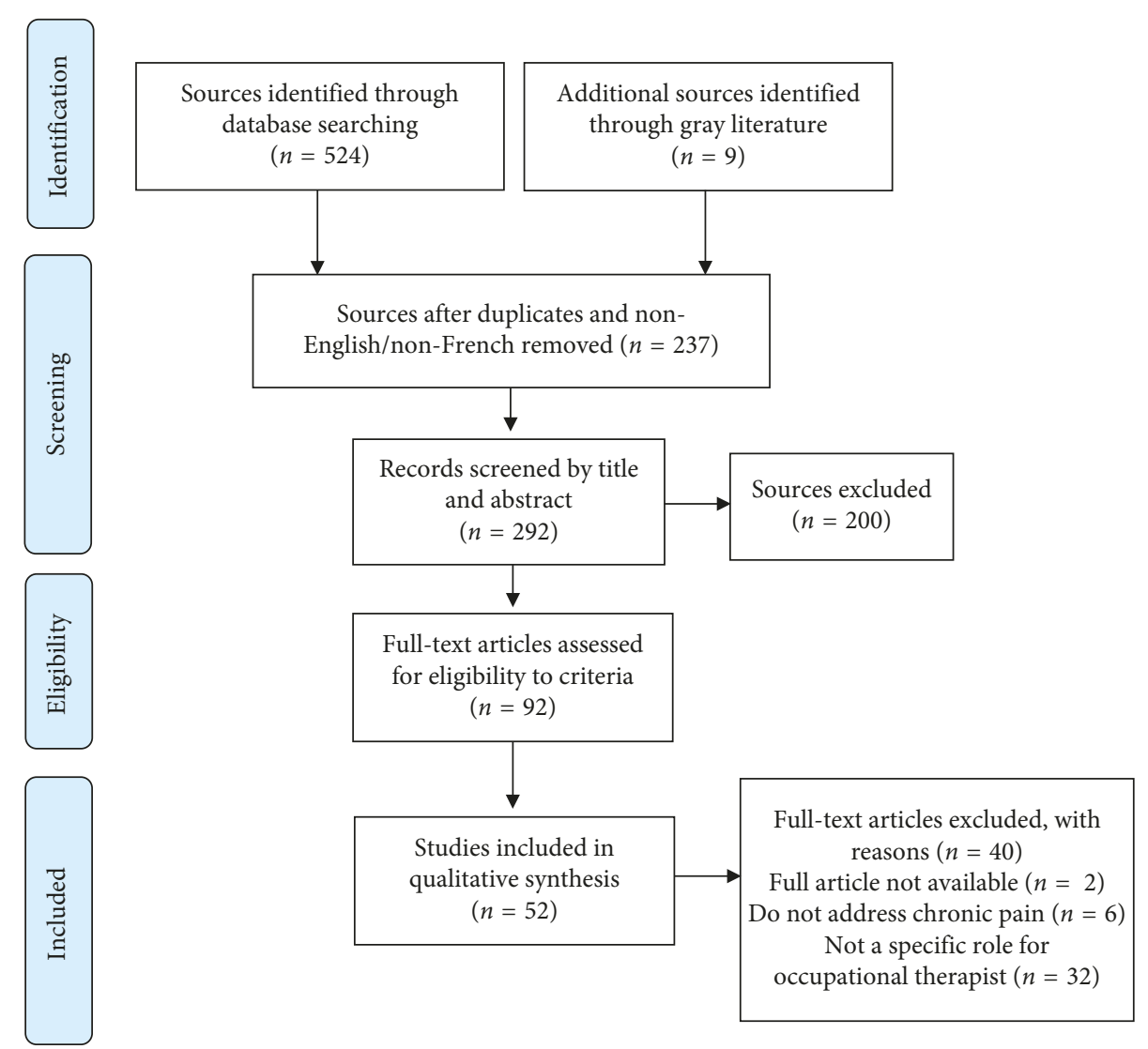

Figure 1: Flowchart of sources screened and included in the scoping review.

Frequency analysis was used to identify the number of sources and the characteristics related to the categories.

\section{Results}

A total of 52 sources were included in this scoping review: 19 reviews, 13 empirical studies, 7 qualitative studies, 6 documents from the gray literature, 3 descriptive studies, 3 author opinions, and 1 mixed-method study. These sources originated in the USA $(n=21 ; 40.4 \%)$, Canada $(n=8$; $15.4 \%)$, Sweden $(n=6 ; 11.5 \%)$, Spain $(n=3 ; 7.8 \%)$, Australia, France, Ireland, Germany, Netherlands $(n=2$ for each of them; 3.8\%), Belgium, Denmark, Swiss, and United Kingdom ( $n=1$ for each of them; $1.9 \%$ ). Table 2 presents the synthesized results.

3.1. Occupational Therapy Roles. Occupational therapists in CP management suit different roles as shown in Table 3. They may be classified according to the ICF.

3.1.1. Activities and Participation. The most frequently reported OT role in CP management ( $n=40 / 52 ; 76.9 \%)$ was to improve activities and participation and was distributed in the following way: enabling occupational engagement $(n=20 ; 38.5 \%)$ and occupational performance $(n=15$; $28.8 \%)$, providing vocational rehabilitation $(n=11 ; 21.2 \%)$, promoting participation $(n=5 ; 9.6 \%)$, promoting functional independence, mobility, and autonomy ( $n=5 ; 9.6 \%)$, addressing occupational balance $(n=4 ; 7.7 \%)$, restoring occupational identity $(n=2 ; 3.8 \%)$, and limiting occupational injustice $(n=1 ; 1.9 \%)$.

3.1.2. Body Functions and Structures. Improving and restoring function ( $n=5 ; 9.6 \%)$, as well as improving body mechanics and activity tolerance $(n=2 ; 3.8 \%)$, were mentioned as part of the OT role in CP management.

3.1.3. Environmental Factors. OT involvement in modifying the nonhuman environment and adopting an ergonomic approach $(n=17 ; 32.7 \%)$ and in enhancing social support $(n=8 ; 15.4 \%)$ for adults with CP was mentioned by some authors.

3.1.4. Personal Factors. Most of the sources pertained to general CP in adults $(n=28 ; 53.8 \%)$, followed by chronic low back pain $(n=10 ; 19.2 \%)$, fibromyalgia $(n=6 ; 11.5 \%)$, complex regional pain syndrome $(n=5 ; 9.6 \%)$, headaches $(n=2 ; 3.8 \%)$, and chronic shoulder pain $(n=1 ; 1.9 \%)$.

3.2. Occupational Therapy Models and Conceptual Frameworks. The models and conceptual frameworks reported are summarized in Table 4. In order to specifically address occupational issues linked to $\mathrm{CP}$, the authors directed 
TABLE 2: Summary of publications in the final analysis $(n=52)$.

\begin{tabular}{|c|c|c|c|c|}
\hline $\begin{array}{l}\text { Author(s), year, } \\
\text { country of origin }\end{array}$ & Aim/purpose & Sample size & Study population & Type of publication \\
\hline $\begin{array}{l}\text { Aegle and Satink [30] } \\
\text { Netherlands }\end{array}$ & $\begin{array}{l}\text { To explore how persons } \\
\text { with chronic pain } \\
\text { experienced their } \\
\text { occupational performance. }\end{array}$ & $n=8$ subjects & $\mathrm{CP}$ & Qualitative study \\
\hline $\begin{array}{l}\text { Artner et al. [31] } \\
\text { Germany }\end{array}$ & $\begin{array}{l}\text { To introduce and evaluate } \\
\text { the short-term outcome of } \\
\text { a three-week intensive } \\
\text { multidisciplinary } \\
\text { outpatient program for } \\
\text { patients with back pain and } \\
\text { sciatica, measured } \\
\text { according to decrease of } \\
\text { functional impairment and } \\
\text { pain. }\end{array}$ & $n=160$ subjects & Chronic LBP & $\begin{array}{l}\text { Pilot study (retrospective } \\
\text { analysis) }\end{array}$ \\
\hline $\begin{array}{l}\text { Ashby et al. [32] } \\
\text { Australia }\end{array}$ & $\begin{array}{l}\text { To examine the difficulties } \\
\text { men with chronic LBP } \\
\text { experienced in the } \\
\text { maintenance of their } \\
\text { leisure activities and to } \\
\text { explore the connection } \\
\text { between leisure and social } \\
\text { networks and the potential } \\
\text { barriers to resuming leisure } \\
\text { occupations due to chronic } \\
\text { LBP. }\end{array}$ & $n=11$ patients (men) & Chronic LBP & Ethnographic study \\
\hline $\begin{array}{l}\text { Bosy et al. [33] } \\
\text { Canada }\end{array}$ & $\begin{array}{l}\text { To describe the essential } \\
\text { elements of an intensive } 8 \text { - } \\
\text { week interdisciplinary pain } \\
\text { rehabilitation programme } \\
\text { with a cognitive-behavioral } \\
\text { emphasis and the results } \\
\text { that can be expected in } \\
\text { treating patients with } \\
\text { chronic pain conditions. }\end{array}$ & $n=338$ patients & $\mathrm{CP}$ & Observational study \\
\hline $\begin{array}{l}\text { Caby et al. [34] } \\
\text { France }\end{array}$ & $\begin{array}{c}\text { To evaluate the efficiency of } \\
\text { an intensive, dynamic, and } \\
\text { multidisciplinary } \\
\text { functional restoration } \\
\text { program in patients with } \\
\text { chronic LBP, during 6- } \\
\text { month follow-up and 12- } \\
\text { month follow-up. }\end{array}$ & $n=144$ patients & Chronic LBP & $\begin{array}{l}\text { Retrospective, } \\
\text { nonrandomized controlled } \\
\text { study }\end{array}$ \\
\hline $\begin{array}{l}\text { Cammalleri [35] } \\
\text { Canada }\end{array}$ & $\begin{array}{l}\text { To specifically look at the } \\
\text { relationships between } \\
\text { religion and pain } \\
\text { experiences. }\end{array}$ & $n=2$ women & $\mathrm{CP}$ & $\begin{array}{c}\text { Gray literature/dissertation } \\
\text { qualitative study }\end{array}$ \\
\hline $\begin{array}{l}\text { Demoulin et al. [36] } \\
\text { Belgium }\end{array}$ & $\begin{array}{l}\text { To evaluate the efficacy of } \\
\text { a semi-intensive } \\
\text { multidisciplinary } \\
\text { outpatient program } \\
\text { complying with the } \\
\text { requirements of the } \\
\text { Belgian National Institute } \\
\text { for Health and Disability } \\
\text { Insurance and intended for } \\
\text { patients with chronic LBP. }\end{array}$ & $n=262$ patients & Chronic LBP & $\begin{array}{l}\text { Pretest-posttest with } \\
\text { a control group }\end{array}$ \\
\hline
\end{tabular}


TABle 2: Continued.

\begin{tabular}{|c|c|c|c|c|}
\hline $\begin{array}{l}\text { Author(s), year, } \\
\text { country of origin }\end{array}$ & Aim/purpose & Sample size & Study population & Type of publication \\
\hline $\begin{array}{l}\text { Dobkin et al. [37] } \\
\text { Canada }\end{array}$ & $\begin{array}{c}\text { To identify factors } \\
\text { associated with decreased } \\
\text { disability and lower pain } \\
\text { scores } 6 \text { months after } \\
\text { a multimodal treatment } \\
\text { program for FM and to } \\
\text { determine whether } \\
\text { adherence influenced } \\
\text { outcomes. }\end{array}$ & $n=46$ women & FM & Quasiexperimental study \\
\hline Fisher et al. [13] USA & $\begin{array}{c}\text { To explore the lived } \\
\text { occupational experiences } \\
\text { of people who have chronic } \\
\text { pain. }\end{array}$ & $n=13$ patients & $\mathrm{CP}$ & $\begin{array}{c}\text { Qualitative } \\
\text { phenomenological study }\end{array}$ \\
\hline Fisher et al. [38] USA & $\begin{array}{l}\text { To develop an occupation- } \\
\text { based assessment that } \\
\text { measured and described } \\
\text { the occupational } \\
\text { performance of individuals } \\
\text { with CP. }\end{array}$ & $\begin{array}{l}n=25 \text { patients }+17 \\
\text { practicing occupational } \\
\text { therapists }\end{array}$ & $\mathrm{CP}$ & Methodological study \\
\hline $\begin{array}{l}\text { Gallice et al. [39] } \\
\text { Swiss }\end{array}$ & $\begin{array}{l}\text { To present the practice of } \\
\text { a multidisciplinary } \\
\text { functional rehabilitation } \\
\text { program for patients with } \\
\text { chronic LBP. }\end{array}$ & - & Chronic LBP & Author opinion \\
\hline $\begin{array}{l}\text { Gatchel and Dougall } \\
\text { [40] USA }\end{array}$ & $\begin{array}{l}\text { This chapter reviews and } \\
\text { discusses data } \\
\text { demonstrating the close } \\
\text { comorbidity between } \\
\text { chronic musculoskeletal } \\
\text { and mental health } \\
\text { disorders. }\end{array}$ & - & $\mathrm{CP}$ & $\begin{array}{l}\text { Gray literature book } \\
\text { chapter } 12\end{array}$ \\
\hline $\begin{array}{l}\text { Lippe and Polatin } \\
\text { [41] USA }\end{array}$ & $\begin{array}{l}\text { This chapter describes the } \\
\text { basic rationale behind an } \\
\text { interdisciplinary approach, } \\
\text { the interdisciplinary } \\
\text { program framework, and } \\
\text { the role that this approach } \\
\text { plays when considering } \\
\text { disability in the workplace. }\end{array}$ & - & $\mathrm{CP}$ & $\begin{array}{l}\text { Gray literature book } \\
\text { chapter } 20\end{array}$ \\
\hline $\begin{array}{l}\text { Chapman et al. [42] } \\
\text { USA }\end{array}$ & $\begin{array}{l}\text { This chapter discusses four } \\
\text { important areas related to } \\
\text { vocational assessment and } \\
\text { training for patients with } \\
\text { chronic musculoskeletal } \\
\text { disorders. }\end{array}$ & - & $\mathrm{CP}$ & $\begin{array}{l}\text { Gray literature book } \\
\text { chapter } 25\end{array}$ \\
\hline $\begin{array}{l}\text { Gonzalez et al. [43] } \\
\text { Spain }\end{array}$ & $\begin{array}{l}\text { To evaluate the } \\
\text { improvement of ADL and } \\
\text { quality of life following } \\
\text { a multidisciplinary } \\
\text { intervention (health } \\
\text { primary care and } \\
\text { occupational therapy). }\end{array}$ & $n=21$ patients & FM & Pretest-posttest study \\
\hline $\begin{array}{l}\text { Harden et al. [44] } \\
\text { USA }\end{array}$ & $\begin{array}{l}\text { To provide treatment } \\
\text { guidelines for CRPS. }\end{array}$ & - & CRPS & Literature review \\
\hline $\begin{array}{l}\text { Harden et al. [45] } \\
\text { USA }\end{array}$ & $\begin{array}{l}\text { To provide diagnostic and } \\
\text { treatment guidelines for } \\
\text { CRPS. }\end{array}$ & - & CRPS & Literature review \\
\hline
\end{tabular}


TABle 2: Continued.

\begin{tabular}{|c|c|c|c|c|}
\hline $\begin{array}{l}\text { Author(s), year, } \\
\text { country of origin }\end{array}$ & Aim/purpose & Sample size & Study population & Type of publication \\
\hline $\begin{array}{l}\text { Hardison and Roll } \\
\text { [46] USA }\end{array}$ & $\begin{array}{l}\text { To describe how } \\
\text { mindfulness is used in } \\
\text { physical rehabilitation, } \\
\text { identify implications for } \\
\text { OT practice, and guide } \\
\text { future research on clinical } \\
\text { mindfulness interventions. }\end{array}$ & $n=16$ sources & $\mathrm{CP}$ & Scoping review \\
\hline $\begin{array}{l}\text { Hesselstrand et al. } \\
\text { [23] Sweden }\end{array}$ & $\begin{array}{l}\text { To assess the quality of } \\
\text { studies describing and } \\
\text { evaluating the effects of OT } \\
\text { interventions on CP. }\end{array}$ & $n=19$ studies & $\mathrm{CP}$ & $\begin{array}{c}\text { Systematic literature } \\
\text { review }\end{array}$ \\
\hline $\begin{array}{l}\text { Hill [12] United } \\
\text { Kingdom }\end{array}$ & $\begin{array}{l}\text { To explain the role and } \\
\text { value of OT within the pain } \\
\text { management team. }\end{array}$ & - & $\mathrm{CP}$ & Author opinion \\
\hline Jarrar [47] USA & $\begin{array}{l}\text { To evaluate the effects of } \\
\text { mirror therapy on upper } \\
\text { extremity pain and } \\
\text { function for individuals } \\
\text { with CRPS. }\end{array}$ & $n=1$ (case study) & CRPS & $\begin{array}{c}\text { Gray literature/thesis } \\
\text { systematic review and case } \\
\text { study }\end{array}$ \\
\hline $\begin{array}{l}\text { Kallhed and } \\
\text { Mårtensson [48] } \\
\text { Sweden }\end{array}$ & $\begin{array}{c}\text { To explore how persons } \\
\text { with CP reason about their } \\
\text { use and choice of strategies } \\
\text { to manage activities of } \\
\text { everyday life. }\end{array}$ & $n=8$ persons & $\mathrm{CP}$ & $\begin{array}{l}\text { Qualitative study } \\
\text { (semistructured } \\
\text { interviews) }\end{array}$ \\
\hline $\begin{array}{l}\text { Keponen and } \\
\text { Kielhofner [49] USA }\end{array}$ & $\begin{array}{l}\text { To examine how women } \\
\text { experience occupations as } \\
\text { they live with CP and more } \\
\text { specifically to gain detailed } \\
\text { knowledge regarding the } \\
\text { meaning of important } \\
\text { occupations in their life. }\end{array}$ & $n=17$ narratives & $\mathrm{CP}$ & $\begin{array}{l}\text { Qualitative study } \\
\text { (narrative study) }\end{array}$ \\
\hline King [50] USA & $\begin{array}{c}\text { To discuss the } \\
\text { nonpharmacologic } \\
\text { therapies for managing CP. }\end{array}$ & - & $\mathrm{CP}$ & Literature review \\
\hline $\begin{array}{l}\text { Kurklinsky et al. [51] } \\
\text { USA }\end{array}$ & $\begin{array}{l}\text { To examine the efficacy of } \\
\text { interdisciplinary } \\
\text { rehabilitation for } \\
\text { improving function in } \\
\text { people with CP. }\end{array}$ & $n=150$ patients & $\mathrm{CP}$ & Retrospective chart review \\
\hline $\begin{array}{l}\text { Linden et al. [52] } \\
\text { Germany }\end{array}$ & $\begin{array}{l}\text { To evaluate the } \\
\text { effectiveness of cognitive } \\
\text { behaviour group therapy in } \\
\text { respect to pain tolerance } \\
\text { and disability apart from } \\
\text { the effects on somatization } \\
\text { in general and additional to } \\
\text { the effects of a multimodal } \\
\text { inpatient orthopedic } \\
\text { rehabilitation program. }\end{array}$ & $\begin{array}{l}\quad n=103 \text { patients ( } 53 \\
\text { patients with chronic LBP } \\
\text { and } 50 \text { controls) }\end{array}$ & Chronic LBP & $\begin{array}{l}\text { Randomized controlled } \\
\text { trial }\end{array}$ \\
\hline Mathews [53] USA & $\begin{array}{l}\text { To discuss the principles of } \\
\text { CP rehabilitation and some } \\
\text { of these modalities in } \\
\text { greater detail. }\end{array}$ & - & $\mathrm{CP}$ & Literature review \\
\hline
\end{tabular}


TABle 2: Continued.

\begin{tabular}{|c|c|c|c|c|}
\hline $\begin{array}{l}\text { Author(s), year, } \\
\text { country of origin }\end{array}$ & Aim/purpose & Sample size & Study population & Type of publication \\
\hline $\begin{array}{l}\text { McCormack and } \\
\text { Gupta [54] USA }\end{array}$ & $\begin{array}{l}\text { To discuss and illustrate the } \\
\text { use of complementary } \\
\text { approaches to pain } \\
\text { management by } \\
\text { occupational therapists. }\end{array}$ & - & $\mathrm{CP}$ & Literature review \\
\hline McLean [55] Canada & $\begin{array}{l}\text { To report tools those } \\
\text { occupational therapists or } \\
\text { other clinicians may use to } \\
\text { provide support to } \\
\text { migraineurs (and their } \\
\text { employer) in the } \\
\text { workplace. }\end{array}$ & - & Headache & Literature review \\
\hline $\begin{array}{l}\text { McLean et al. [56] } \\
\text { Canada }\end{array}$ & $\begin{array}{l}\text { To review the pacing } \\
\text { literature; describe the use } \\
\text { of pacing in a specialty } \\
\text { headache clinic; and } \\
\text { provide client feedback } \\
\text { regarding the effectiveness } \\
\text { of pacing in headache self- } \\
\text { management. }\end{array}$ & $n=20$ patients & Headache & Literature review \\
\hline Miles [57] USA & $\begin{array}{l}\text { To propose } \\
\text { a multidisciplinary pain } \\
\text { treatment program that } \\
\text { aims to reduce the pain and } \\
\text { improve the functioning of } \\
\text { the patient, as well as to } \\
\text { improve the } \\
\text { communication between } \\
\text { specialists to facilitate } \\
\text { patient progress. }\end{array}$ & - & $\mathrm{CP}$ & $\begin{array}{l}\text { Gray literature/dissertation } \\
\text { mixed-methods study }\end{array}$ \\
\hline $\begin{array}{l}\text { Nieuwenhuizen et al. } \\
\text { [58] Netherlands }\end{array}$ & $\begin{array}{l}\text { To examine the construct } \\
\text { validity and construct } \\
\text { responsiveness of the } \\
\text { Dutch version of the } \\
\text { COPM performance scale } \\
\text { in a population with CP. }\end{array}$ & $n=87$ patients & $\mathrm{CP}$ & Methodological study \\
\hline Paquette [59] USA & $\begin{array}{l}\text { To apply the OT framework } \\
\text { along with an evidence- } \\
\text { based approach and an } \\
\text { occupation-based } \\
\text { intervention with } \\
\text { a population of workers } \\
\text { with chronic LBP to help } \\
\text { them return to work and } \\
\text { maintain their work status. }\end{array}$ & - & Chronic LBP & Literature review \\
\hline $\begin{array}{l}\text { Pérez de Heredia- } \\
\text { Torres et al. [60] } \\
\text { Spain }\end{array}$ & $\begin{array}{l}\text { To evaluate the differences } \\
\text { in cognitive skills between } \\
\text { women with FM and } \\
\text { healthy women, and the } \\
\text { correlations between } \\
\text { functional independence } \\
\text { and cognitive limitations. }\end{array}$ & $\begin{array}{c}n=40 \text { patients }(20 \\
\text { controls, } 20 \text { patients with } \\
\text { FM) }\end{array}$ & FM & $\begin{array}{l}\text { Cross-sectional case } \\
\text { control study }\end{array}$ \\
\hline $\begin{array}{l}\text { Perneros and Tropp } \\
\text { [61] Sweden }\end{array}$ & $\begin{array}{c}\text { To present the } \\
\text { development of The } \\
\text { Assessment of Pain and } \\
\text { Occupational Performance } \\
\text { and to evaluate validity and } \\
\text { reliability. }\end{array}$ & $\begin{array}{c}n=220 \text { patients ( } 142 \\
\text { chronic LBP, } 97 \text { specific } \\
\text { LBP, } 45 \text { nonspecific back } \\
\text { pain) }\end{array}$ & $\begin{array}{l}\text { Chronic LBP, specific LBP } \\
\text { and nonspecific back pain }\end{array}$ & $\begin{array}{l}\text { Descriptive longitudinal } \\
\text { study }\end{array}$ \\
\hline
\end{tabular}


TABle 2: Continued.

\begin{tabular}{|c|c|c|c|c|}
\hline $\begin{array}{l}\text { Author(s), year, } \\
\text { country of origin }\end{array}$ & Aim/purpose & Sample size & Study population & Type of publication \\
\hline $\begin{array}{l}\text { Perneros et al. [62] } \\
\text { Sweden }\end{array}$ & $\begin{array}{l}\text { To evaluate occupational } \\
\text { performance and pain } \\
\text { intensity in daily } \\
\text { occupations for patients } \\
\text { with chronic LBP. }\end{array}$ & $n=97$ patients & Chronic LBP & $\begin{array}{l}\text { Descriptive longitudinal } \\
\text { study }\end{array}$ \\
\hline $\begin{array}{l}\text { Persson et al. [63] } \\
\text { Sweden }\end{array}$ & $\begin{array}{c}\text { To describe everyday } \\
\text { occupational problems } \\
\text { among patients with } \\
\text { musculoskeletal pain } \\
\text { enrolled in a pain } \\
\text { rehabilitation programme, } \\
\text { and to compare subgroups } \\
\text { based on participant } \\
\text { characteristics. }\end{array}$ & $n=152$ participants & $\mathrm{CP}$ & Mixed-methods study \\
\hline $\begin{array}{l}\text { Poole and Siegel [64] } \\
\text { USA }\end{array}$ & $\begin{array}{l}\text { To summarize evidence } \\
\text { focused on effectiveness of } \\
\text { OT-related interventions } \\
\text { for adults with FM. }\end{array}$ & $n=42$ sources & FM & Systematic review \\
\hline $\begin{array}{l}\text { Prefontaine and } \\
\text { Rochette [65] Canada }\end{array}$ & $\begin{array}{l}\text { To review the relationship } \\
\text { between } \mathrm{CP} \text { and } \\
\text { engagement in } \\
\text { instrumental ADL, sleep, } \\
\text { and family life. }\end{array}$ & $n=13$ sources & $\mathrm{CP}$ & Literature review \\
\hline $\begin{array}{l}\text { Ravenek et al. [66] } \\
\text { Canada }\end{array}$ & $\begin{array}{l}\text { To update the evidence for } \\
\text { the multidisciplinary } \\
\text { treatment of chronic LBP } \\
\text { to improve employment } \\
\text { outcomes and to assess } \\
\text { what knowledge supports } \\
\text { OT as contributing to } \\
\text { a multidisciplinary } \\
\text { approach in the treatment } \\
\text { of chronic LBP. }\end{array}$ & $n=12$ sources & Chronic LBP & Systematic review \\
\hline $\begin{array}{l}\text { Robinson et al. [67] } \\
\text { Ireland }\end{array}$ & $\begin{array}{l}\text { To critically analyse OT } \\
\text { services for people with CP } \\
\text { and identify significant } \\
\text { factors influencing the } \\
\text { future development of OT } \\
\text { services for people with CP. }\end{array}$ & - & $\mathrm{CP}$ & Literature review \\
\hline $\begin{array}{l}\text { Robinson et al. [19] } \\
\text { Ireland }\end{array}$ & $\begin{array}{l}\text { To discuss contemporary } \\
\text { OT for people with CP with } \\
\text { reference to a broad range } \\
\text { of literature from many } \\
\text { disciplines, and to examine } \\
\text { the success of OT services } \\
\text { in meeting the } \\
\text { occupational needs of } \\
\text { people with CP. }\end{array}$ & - & $\mathrm{CP}$ & Author opinion \\
\hline Rome [68] France & $\begin{array}{l}\text { To assess the value of } \\
\text { combining OT with } \\
\text { physical therapy for the } \\
\text { rehabilitation of CRPS and } \\
\text { to measure its effectiveness } \\
\text { on ADL. }\end{array}$ & $n=60$ patients & CRPS type 1 & Comparative cases study \\
\hline
\end{tabular}


TABLE 2: Continued.

\begin{tabular}{|c|c|c|c|c|}
\hline $\begin{array}{l}\text { Author(s), year, } \\
\text { country of origin }\end{array}$ & Aim/purpose & Sample size & Study population & Type of publication \\
\hline $\begin{array}{l}\text { Salgueiro et al. [69] } \\
\text { Spain }\end{array}$ & $\begin{array}{l}\text { To evaluate the ability of } \\
\text { artificial neural networks to } \\
\text { predict, on the basis of } \\
\text { clinical variables, the } \\
\text { response of persons with } \\
\text { FM syndrome to } \\
\text { a standard, 4-week } \\
\text { interdisciplinary pain } \\
\text { program. }\end{array}$ & $n=71$ patients & FM & $\begin{array}{l}\text { Retrospective longitudinal } \\
\text { study }\end{array}$ \\
\hline Silvestri [21] USA & $\begin{array}{c}\text { To examine the } \\
\text { implications of chronic } \\
\text { shoulder pain on quality of } \\
\text { life and occupational } \\
\text { engagement in spinal cord } \\
\text { injury. }\end{array}$ & - & Chronic shoulder pain & Literature review \\
\hline $\begin{array}{l}\text { Simon and Collins } \\
\text { [70] USA }\end{array}$ & $\begin{array}{l}\text { To determine the efficacy of } \\
\text { a lifestyle Redesign }{ }^{\circledR} \\
\text { intervention for people } \\
\text { living with CP on quality of } \\
\text { life, function, self-efficacy, } \\
\text { and pain levels. }\end{array}$ & $n=45$ patients & $\begin{array}{l}\text { CP-chronic LBP, myalgia } \\
\text { (FM), and CRPS }\end{array}$ & Retrospective study \\
\hline $\begin{array}{l}\text { Skjutar et al. [20] } \\
\text { Sweden }\end{array}$ & $\begin{array}{l}\text { To explore occupational } \\
\text { therapists' perceptions of } \\
\text { indicators for OT } \\
\text { interventions among } \\
\text { patients with CP. }\end{array}$ & $\begin{array}{c}n=25 \text { occupational } \\
\text { therapists }\end{array}$ & $\mathrm{CP}$ & $\begin{array}{l}\text { Qualitative study (focus } \\
\text { group) }\end{array}$ \\
\hline Stanos [71] USA & $\begin{array}{l}\text { To examine components of } \\
\text { interdisciplinary pain } \\
\text { rehabilitation programs, to } \\
\text { discuss desirable features } \\
\text { of successful programs and } \\
\text { teams, and to review four } \\
\text { established outpatient pain } \\
\text { programs in the United } \\
\text { States. }\end{array}$ & $n=4($ program $)$ & $\mathrm{CP}$ & Focused review \\
\hline $\begin{array}{l}\text { Stewart et al. [72] } \\
\text { USA }\end{array}$ & $\begin{array}{l}\text { To offer perspectives from } \\
\text { life care planners, an } \\
\text { occupational therapist, } \\
\text { rehabilitation counsellors, } \\
\text { and a pain management } \\
\text { specialist on CP treatment. }\end{array}$ & - & $\mathrm{CP}$ & Literature review \\
\hline $\begin{array}{l}\text { Tran et al. [73] } \\
\text { Canada }\end{array}$ & $\begin{array}{l}\text { To summarize the evidence } \\
\text { derived from randomized } \\
\text { controlled trials pertaining } \\
\text { to the treatment of CRPS. }\end{array}$ & $n=41$ sources & CRPS & Narrative review \\
\hline $\begin{array}{l}\text { van Huet et al. [74] } \\
\text { Australia }\end{array}$ & $\begin{array}{l}\text { To explore factors that } \\
\text { contribute to clients' CP } \\
\text { management from an OT } \\
\text { perspective. }\end{array}$ & $\begin{array}{c}n=9 \text { occupational } \\
\text { therapists }\end{array}$ & $\mathrm{CP}$ & $\begin{array}{l}\text { Qualitative study } \\
\text { (narrative inquiry) }\end{array}$ \\
\hline $\begin{array}{l}\text { Von Bülow et al. [75] } \\
\text { Denmark }\end{array}$ & $\begin{array}{l}\text { To identify frequently } \\
\text { reported ADL skill deficits } \\
\text { of significance in } \\
\text { subgroups of women with } \\
\text { FM who have decreased } \\
\text { ADL motor ability in } \\
\text { combination with } \\
\text { decreased or competent } \\
\text { ADL process ability. }\end{array}$ & $n=188$ patients & FM & Cross-sectional study \\
\hline
\end{tabular}

Note. $\mathrm{ADL}=$ activities of daily living; $\mathrm{COPM}=$ Canadian occupational performance measure; $\mathrm{CP}=$ chronic pain; $\mathrm{CRPS}=$ complex regional pain syndrome; $\mathrm{FM}=$ fibromyalgia $\mathrm{LBP}=$ low back pain; $\mathrm{OT}=$ occupational therapy. 
TABLE 3: Occupational therapy roles in chronic pain management.

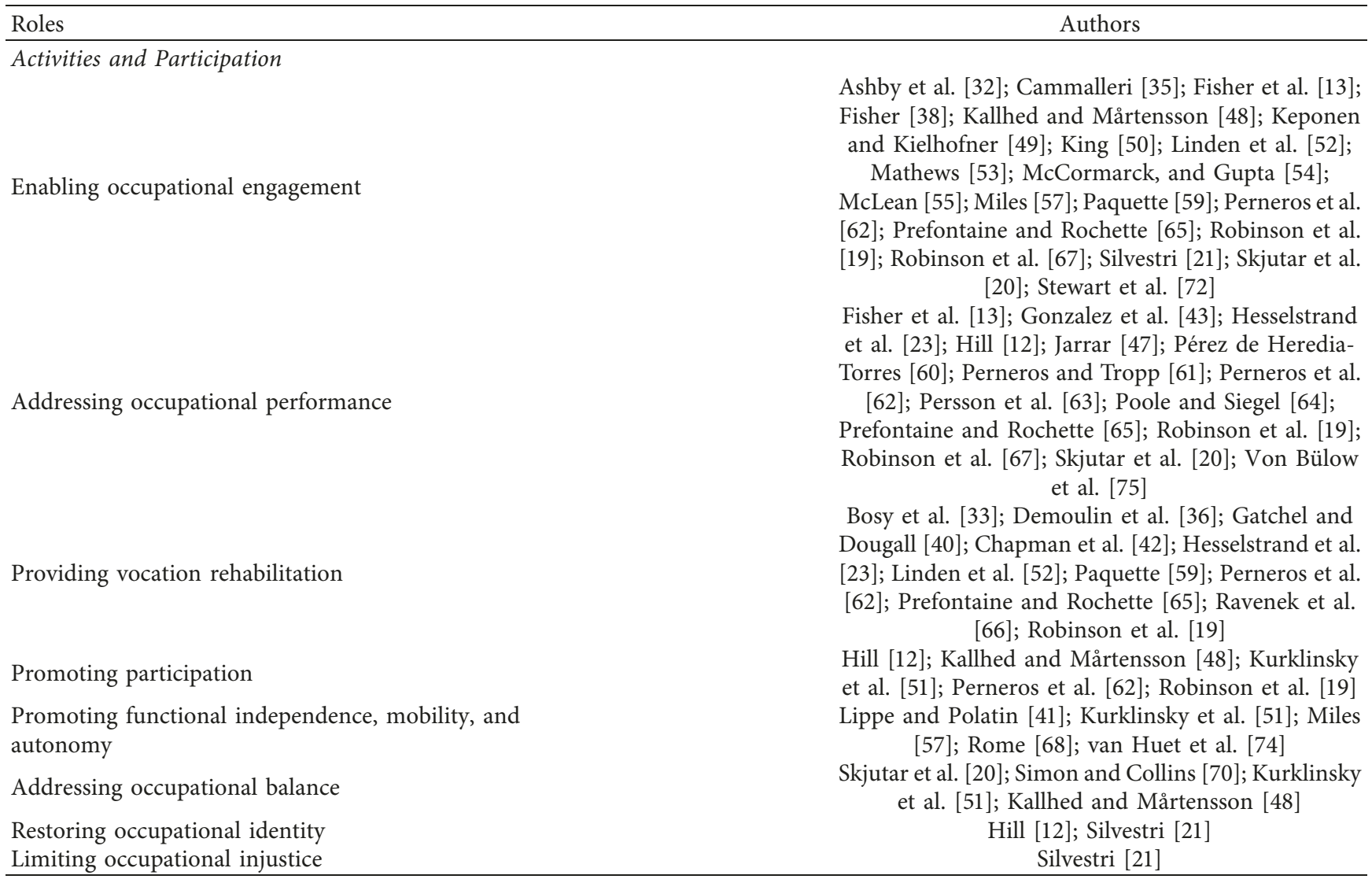

Body functions and structures

Harden et al. [44]; Harden et al. [45]; Jarrar [47]; King

Improving/Restoring function

[50]; Mathews [53]

Improving body mechanics and activity tolerance Miles [57]; Stanos [71]

Environmental factors

Modifying the nonhuman environment and

ergonomic approach

Artner et al. [31]; Bosy et al. [33]; Caby et al. [34]; Chapman et al. [42]; Demoulin et al. [36]; Gallice et al. [39]; Hesseltrand et al. [23]; Hill [12]; Kallhed and Mårtensson [48]; Kurklinsky et al. [51]; Mathews [53]; Miles [57]; Ravenek et al. [66]; Robinson et al. [19]; Salgueiro et al. [69]; Stanos [71]; Stewart et al. [72]

Ashby et al. [32]; Gonzalez et al. [43]; Hill [12];

Enhancing social support

Paquette [59]; Perneros and Tropp [61]; Perneros et al. [62]; Simon and Collins [70]; Ravenek et al. [66]

their attention towards disciplinary OT models of practice and practice frameworks. The ones that were mentioned the most where the Canadian Model of Occupational Performance (CMOP) $(n=5 ; 9.6 \%)$ and the Canadian Model of Occupational Performance and Engagement (CMOP-E) $(n=1$; $1.9 \%)$. The CMOP specifies three core constructs of interest for the profession of OT (persons, environments, and occupations) and portrays occupational performance as the result of their dynamic interaction $[11,76]$. To extend its occupation-based perspective, engagement was added as a conceptual advancement on the original model [77]. Other models of practice are reported such as the Occupational Therapy Practice Framework: Domain and Process $(n=7$; 13.5\%). This practice framework provides a systematic method of combining a variety of theoretical conceptual practice models to address a client's issues more comprehensively and guides occupational therapists towards combining multiple theoretical models to address client occupational performance issues and in defending their clinical decisions effectively [78].

3.3. Occupational Therapy Assessments. Table 5 summarizes the main domains of assessment methods of occupational therapists in $\mathrm{CP}$ management. The most reported measurement tool was the Canadian Occupational Performance Measure (COPM) $(n=11 ; 21.2 \%)$. Other evidencebased outcome assessments included the Occupational 
TABLE 4: Occupational therapy models of practice and practice framework in chronic pain management.

\begin{tabular}{lc}
\hline Occupation-based model/framework & Authors \\
\hline Models of Practice & Cammalleri [35]; Jarrar [47]; Nieuwenhuizen et al. \\
Canadian Model of Occupational Performance & [58]; Perneros and Tropp [61]; Persson et al. [63] \\
(CMOP) & Prefontaine and Rochette [65] \\
Canadian Model of Occupational Performance and & Keponen and Kielhofner [49] \\
Engagement (CMOP-E) & Silvestri [21] \\
Model of Human Occupation (MOHO) & McLean et al. [56] \\
Ecology of Human Performance (EHP) Model & Cammalleri [35] \\
Occupational Performance Model (OPM) & Kallhed and Mårtensson [48] \\
Kawa Model & Aegle and Satink [30] \\
Value and Meaning in Occupations (ValMO) &
\end{tabular}

Practice Framework

Occupational Therapy Practice Framework: Domain and Process
Fisher et al. [38]; Hardison and Roll [46]; Jarrar [47]; McCormack and Gupta [54]; Paquette [59]; Poole and Siegel [64]; Simon and Collins [70]

TABLE 5: Occupational therapy assessments in chronic pain management.

\begin{tabular}{lc}
\hline Occupational therapy-used assessments & Authors \\
\hline Evidence-based outcome measure & $\begin{array}{r}\text { Fisher et al. [38]; Hesselstrand et al. [23]; Jarrar [47]; } \\
\text { Kurklinsky et al. [51]; Nieuwenhuizen et al. [58]; } \\
\text { Perneros et al. [62]; Persson et al. [63]; Prefontaine } \\
\text { and Rochette [65]; Simon and Collins [70]; Stanos } \\
\text { [71]; van Huet et al. [74] }\end{array}$ \\
$\begin{array}{l}\text { Canadian Occupational Performance Measure } \\
\text { (COPM) }\end{array}$ & $\begin{array}{c}\text { Fisher et al. [38]; Keponen and Kielhofner [49]; } \\
\text { Prefontaine and Rochette [65] }\end{array}$ \\
$\begin{array}{l}\text { Occupational Performance History Interview (OPHI- } \\
\text { II) }\end{array}$ & $\begin{array}{c}\text { Perneros and Tropp [61]; Perneros et al. [62] } \\
\text { Assessment of Pain And Occupational Performance } \\
\text { (POP) }\end{array}$ \\
$\begin{array}{l}\text { Functional Independence Measure (FIM) } \\
\text { Milliken Activities of Daily Living Scale (MAS) }\end{array}$ & $\begin{array}{c}\text { Pérez de Heredia-Torres et al. [60] } \\
\text { Assessment of Motor and Process Skills (AMPS) }\end{array}$ \\
$\begin{array}{l}\text { Assessment of Life Habits Questionnaire (LIFE-H) } \\
\text { Impact on Participation and Autonomy (IPA) } \\
\text { Pain and Functional Performance Assessment } \\
\text { (PFPA) }\end{array}$ & $\begin{array}{c}\text { Rome [68] } \\
\text { Voulow et al. [75] }\end{array}$ \\
\hline
\end{tabular}

Assessment Domain

Work (vocational) assessment or job-site analysis or ergonomic Work Assessment

Analysis of occupational performance, occupation, role, activity and/or participation in ADL

Functional capacity (abilities and limitations) evaluation

Occupational profile/occupational history

Work capacity evaluation/transferable skills analysis

Home assessment
Bosy et al. [33]; Chapman et al. [42]; Gallice et al. [39]; Harden et al. [44]; Harden et al. [45]; Hesselstrand et al. [23]; Hill [12]; McLean [55]; Ravenek et al. [66]; Stanos [71]; van Huet et al. [74]

Ashby et al. [32]; Fisher et al. [38]; Hesselstrand et al. [23]; Hill [12]; Jarrar [47]; McCormack and Gupta

[54]; Mathews [53]; Perneros and Tropp [61]; Perneros et al. [62]

Gallice et al. [39]; Harden et al. [44]; Harden et al. [45]; Hesselstrand et al. [23]; Paquette [59]; Stanos [71]

Mathews [53]; McCormack and Gupta [54] Harden et al. [44]; Harden et al. [45] Hill [12]; van Huet et al. [74]
Performance History Interview (OPHI-II) $(n=3 ; 5.8 \%)$ and the Assessment of Pain and Occupational Performance (POP) $(n=2 ; 3.8 \%)$. The following assessment methods were mentioned in only one source: the Functional Independence Measure (FIM) [60]; the Milliken Activities of
Daily Living Scale (MAS) [47]; the Assessment of Motor and Process Skills (AMPS) [75]; the Assessment of Life Habits Questionnaire (LIFE-H) [68]; the Impact on Participation and Autonomy (IPA) [58]; and the Pain and Functional Performance Assessment (PFPA) [38]. 
TABLE 6: Occupational therapy interventions in chronic pain management.

Treatment methods
Focus on PERSON (training, skill development, and education)

Body mechanics/postures and positioning

Energy conservation/joint-sparing techniques

Relaxation training/stress management

Exercises/fitness program

Mindfulness

Cognitive behavioral therapy/behavioral approaches

Coping strategies

Coordination/dexterity, strengthening tasks

Desensitization techniques/sensory reeducation

Active movements/mobilization techniques

Biofeedback

Functional splinting

Oedema modalities

Proprioceptive neuromuscular

facilitation/reeducation

Thermal modalities

Graded motor imagery

Mirror visual feedback

Stress loading

Breathing techniques

Electrical stimulation

Massage/acupressure

Mental imagery/visualization

Focus on ENVIRONMENT (environmental modification, support provision, and support enhancement)

Ergonomics (home, work, and equipment)

Environmental modification
Artner et al. [31]; Bosy et al. [33]; Caby et al. [34];

Demoulin et al. [36]; Chapman et al. [42];

Hesselstrand et al. [23]; Hill [12]; Kallhed and 2010 [37]; Cammalleri [35]; Chapman et al. [42];

Kurklinsky et al. [51]; Mathews [53]; Nieuwenhuizen et al. [58]; Robinson et al. [19]; Simon and Collins

[70]; Stanos [71]; Stewart et al. [72]; Tran et al. [73]; van Huet et al. [74]

Bosy et al. [33]; Cammalleri [35]; Hesselstrand et al. [23]; Hill [12]; McLean [55]; Robinson et al. [19];

Simon and Collins [70]; Skjutar et al. [20]; van Huet et al. [74]

Fisher et al. [13]; Hill [12]; McLean [55]; Poole and Siegel [64]; Robinson et al. [19]; Robinson et al. [67];

Simon and Collins [70]; van Huet et al. [74]

Cammalleri [35]; Kallhed and Mårtensson [48];

Paquette [59]; Poole and Siegel [64]; Ravenek et al.

[66]; Robinson et al. [19]; Simon and Collins [70]

Hardison and Roll [46]; Hesselstrand et al. [23];

Kallhed and Mårtensson [48]; McCormack and

Gupta [54]; Poole and Siegel [64]; Robinson et al. [19]

Miles [57]; Poole and Siegel [64]; Robinson et al. [19];

Robinson et al. [67]; Simon and Collins [70]; van Huet et al. [74]

Fisher et al. [13]; Gatchel and Dougall [40]; Hill [12]; Skjutar et al. [20]; Stewart et al. [72]

Harden et al. [44]; Harden et al. [45]; Jarrar [47]; Mathews [53]; Rome [68]

Harden et al. [44]; Jarrar [47]; Mathews [53]; Rome [68]; Tran et al. [73]

Harden et al. [44]; Harden et al. [45]; Robinson et al. [19]

Kurklinsky et al. [51]; Ravenek et al. [66]; Robinson et al. [19]

Harden et al. [44]; Robinson et al. [19]; Robinson et al. [67]

Harden et al. [44]; Harden et al. [45]; Tran et al. [73]

Harden et al. [44]; Harden et al. [45]; Stewart et al. [72]

Cammalleri [35]; Robinson et al. [19]

Harden et al. [45]; Tran et al. [73]

Harden et al. [45]; Jarrar [47]

Harden et al. [44]; Harden et al. [45]

McCormack and Gupta [54]

Robinson et al. [19]

McCormack and Gupta [54]

McCormack and Gupta [54]

Mårtensson [48]; Kurklinsky et al. [51]; Mathews

[53]; Ravenek et al. [66]; Robinson et al. [19];

Robinson et al. [67]; Salgueiro et al. [69]; Stanos [71]; Stewart et al. [72]

Artner et al. [31]; Bosy et al. [33]; Hesselstrand et al. [23]; Hill [12]; Kurklinsky et al. [51]; Paquette [59]; Silvestri [21]; Skjutar et al. [20]; Stewart et al. [72];

Ravenek et al. [66]; Von Bülow et al. [75]
Bosy et al. [33]; Demoulin et al. [36]; Dobkin et al. 
TABLE 6: Continued.

\begin{tabular}{|c|c|}
\hline Treatment methods & Authors \\
\hline \multicolumn{2}{|c|}{ Focus on OCCUPATION (task adaptation and occupation development) } \\
\hline \multirow[b]{4}{*}{ Pacing/graded activity } & Bosy et al. [33]; Cammalleri [35]; Dobkin et al. [37]; \\
\hline & Gonzalez et al. [43]; Hesselstrand et al. [23]; Hill [12]; \\
\hline & Kallhed and Mårtensson [48]; Kurklinsky et al. [51]; \\
\hline & McLean [55]; McLean et al. [56]; Nieuwenhuizen \\
\hline & et al. [58]; Paquette [59]; Robinson et al. [19]; \\
\hline & Robinson et al. [67]; Simon and Collins [70]; Stanos \\
\hline \multirow{4}{*}{ Activity (task) adaptation/therapeutically activity } & $\begin{array}{l}\text { [71]; Stewart et al. [72]; van Huet et al. [74] } \\
\text { Cammalleri [35]; Fisher et al. [13]; Gonzalez et al. }\end{array}$ \\
\hline & [43]; Hill [12]; Jarrar [47]; Mathews [53]; McCormack \\
\hline & $\begin{array}{l}\text { and Gupta [54]; Nieuwenhuizen et al. [58]; Paquette } \\
\text { [59]; Ravenek et al. [66]; Robinson et al. [19]; Rome }\end{array}$ \\
\hline & $\begin{array}{l}\text { [68]; Salgueiro et al. [69]; Simon and Collins [70]; } \\
\text { Stewart et al. [72]; Von Bülow et al. [75] }\end{array}$ \\
\hline \multirow{4}{*}{ Vocational intervention } & Bosy et al. [33]; Caby et al. [80]; Demoulin et al. [36]; \\
\hline & Gallice et al. [39]; Chapman et al. [42]; Harden et al. \\
\hline & $\begin{array}{l}\text { [44]; Harden et al. [45]; Hesselstrand et al. [23]; Hill } \\
\text { [12]; Ravenek et al. [66]; Robinson et al. [19]; }\end{array}$ \\
\hline & $\begin{array}{l}\text { Salgueiro et al. [69]; Skjutar et al. [20]; van Huet et al. } \\
\text { [74] }\end{array}$ \\
\hline Sleep hygiene & $\begin{array}{l}\text { Kallhed and Mårtensson [48]; Robinson et al. [19]; } \\
\text { Simon and Collins [70] }\end{array}$ \\
\hline Graded in vivo exposure & Nieuwenhuizen et al. [58]; Robinson et al. [19] \\
\hline Yoga/Tai chi & $\begin{array}{l}\text { Kallhed and Mårtensson [48]; McCormack and } \\
\text { Gupta [54] }\end{array}$ \\
\hline
\end{tabular}

3.4. Occupational Therapy Interventions. OT interventions in CP management were classified according to the intervention taxonomy developed by McColl and Law [79] which categorises eight types of interventions used by occupational therapists to enable occupation as shown in Table 6.

3.4.1. Focus on Person. The most frequently reported interventions are related to body mechanics as well as posture and positioning $(n=14 ; 26.9 \%)$. Energy conservation and joint-sparing techniques $(n=9 ; 17.3 \%)$, relaxation training and stress management $(n=8 ; 15.4 \%)$, and exercises or fitness programs $(n=7 ; 13.5 \%)$ were also mentioned as interventions used in CP management. Moreover, six sources $(n=6 ; 11.5 \%)$ included mindfulness or cognitive behavioral therapy and behavioral approaches. Five sources $(n=5 ; 9.6 \%)$ involved one of the following categories: coping strategies; coordination, dexterity, and strengthening tasks; desensitization techniques; and sensory reeducation. Three sources $(n=3$; $5.8 \%$ ) presented one of the following categories: active movements and mobilization techniques; biofeedback; functional splinting; oedema modalities; and proprioceptive neuromuscular facilitation. Two sources $(n=2 ; 3.8 \%)$ suggested one of the following categories: thermal modalities; graded motor imagery; mirror visual feedback or stress loading. Finally, one source $(n=1 ; 1.9 \%)$ mentioned breathing techniques, electrical stimulation, massage and acupressure, and mental imagery and visualization.

3.4.2. Focus on Environment. The most frequently reported OT interventions addressing the environment related to ergonomics $(n=16 ; 30.8 \%)$ and 11 sources $(n=11 ; 21.2 \%)$ are mentioned environmental modification.

3.4.3. Focus on Occupation. Across all intervention categories, pacing and graded activity $(n=19 ; 36.5 \%)$ and activity (task) adaptation $(n=17 ; 32.7 \%)$ were the most frequently reported OT interventions. Vocational intervention ( $n=14 ; 26.9 \%)$, reeducation, and sleep hygiene $(n=3 ; 5.8 \%)$ were also mentioned as occupation-focused OT interventions. Finally, two sources $(n=2 ; 3.8 \%)$ suggested one of the following categories: graded in vivo exposure, yoga, and Tai Chi.

\section{Discussion}

In this scoping review, current knowledge about OT in $\mathrm{CP}$ management is described after collating and analyzing scientific literature and gray literature about the OT roles, models, assessments, and interventions methods. The results offer insight about OT practice specific to CP management.

4.1. Role. The analysis suggests that occupational therapists mainly aim to improve activities and participation with adults living with CP. This aim is particularly consistent with the top-down approach which adopts a more global perspective of the client's participation in his or her living contexts while considering what is important and relevant to him or her [81]. This aim is aligned with the "participation" level of the ICF [82] and intimately connects to the evidencebased relationship between occupation and health as well as fundamental assumptions in OT regarding how occupations 
influence people's health and vice-versa $[10,83]$. By primarily identifying participation restrictions and understanding their causes, the top-down approach leads to a participation-oriented intervention which can provide $\mathrm{CP}$ clients with the support needed for involvement in their daily activities despite pain and physical impairments, such as a lack of strength or insufficient range of motion.

Whereas a biomedical model of health encourages a technique-oriented practice, an occupation-based practice emphasizes the use of occupation to address the occupational consequences of CP. Our findings show that improving and restoring function as well as improving body mechanics and activity tolerance is part of the aims of occupational therapists in CP management (see Table 3; body functions and structures). An understanding of whether occupational therapists' specificity emerges here while the bottom-up approach to OT interventions is put forward is particularly pressing. Indeed, in 2011, Robinson et al. [67] warned the scientific community that the influence of the biomedical model of health on OT limited the integration of occupation-based practice for people with $\mathrm{CP}$, the latter being the central value of OT. More recently, Burley et al. [84] also witnessed two competing perspectives, biomechanical and occupational, that are present in OT services in the hand therapy literature. They noticed that whilst there has been some integration of an occupational perspective, a bottom-up approach, an inconsistent use of terminology to describe what could be framed as occupations, and a lack of an occupation-based performance perspective persist throughout the OT clinical process. Although this population is not included in this study, these findings demonstrate the continuing tensions between the biomechanical approach and an occupational perspective that can be experienced in the OT profession. Therefore, the best practice requires that occupational therapists thoughtfully elaborate their clinical process without neglecting the purpose and focus of OT, enabling occupation.

4.2. Models. The interactions between $\mathrm{CP}$ and occupation are complex and go well beyond work since personal care, sleep, and family life may also be affected. This is the rational supporting the notion that the complexity of the interactions between all domains of occupation be considered when occupational therapists intervene [65]. Complementary to the biopsychosocial (model or approach), occupationfocused models such as the CMOP/CMOP-E support a holistic understanding and guide the intervention towards the occupational challenges that adults living with $\mathrm{CP}$ face [85]. Moreover, by identifying occupational engagement as an important aspect of human occupation, the CMOP/CMOP-E aligns with the current developments and improvements in knowledge related to occupation-based, client-centered and evidence-based OT practice [77]. Occupational engagement considers meaning, interest, motivation, and/or perceived self-efficacy as criteria necessary for a client-centered practice [6] all of which are of particular interest in the context of CP. The way in which individuals with $\mathrm{CP}$ engage in their daily activities has been shown to impact on daily functioning. Indeed, a growing body of OT research has begun to explore the complexity of the occupational experiences of people living with $\mathrm{CP}[65,86]$ as well as its impact on quality of life [3]. In fact, the relationship between the levels of engagement in occupations and pain experience has been explored $[16,17]$. It has been found that both avoidance of activities and overactivity are associated with more pain, higher levels of physical disability, and poorer psychological functioning [17].

In sum, evidence exists to support the need for OT as an intervention which explicitly endorses an occupation-based perspective. By considering the occupational aspect of living with $\mathrm{CP}$, occupational therapists strengthen and differentiate their role thereby affirming OT specificity within a multidisciplinary team [77].

4.3. Assessment Methods. Historically, bottom-up assessments are frequently used in OT practice and fit within the biomedical model [87]. The approach of using standardized tests and emphasizing physical impairments and disabilities and subsequently inferring their influence on participation restriction may be conducive to communication and may enable a transdisciplinary approach to intervention. However, it is flawed reasoning. Indeed, widespread clinical belief that improvement in body structures and functions reduces activity limitations and participation restrictions has not been convincingly demonstrated in the literature [88]. This scoping review has exposed the challenges of distinguishing the concepts of "activities" and "participation" described in the ICF model. Unfortunately, these concepts are often combined and confounded in contrast with those of body structures and function [89]. For example, questionnaires are typically used to measure the perception of physical functioning in the presence of pain [90] and not the true level of participation. It is important for researchers to keep in mind that participation, which is the concept most closely linked to the occupation-based perspective of OT, differs from activity. Participation refers to involvement in real life situations instead of the execution of a task or action [9], measuring participation can be a challenge but validated tools do exist such as the COPM and the OPHI-II [91] as presented in this review. Occupational therapists should therefore be leaders in implementing these tools in their practice with the adult $\mathrm{CP}$ population.

Occupational therapists can evaluate how pain influences the way an individual performs and engages in his daily occupations [13]. However, another angle that should be assessed is how performance and engagement in daily occupations affect health and well-being in the presence of $\mathrm{CP}$. Our findings show that the most frequently reported assessment method was the COPM. This evidence-based outcome measure is designed to detect change in the client's self-perception of performance and satisfaction in self-care, productivity, and leisure occupations over time [92] and has recently been used to the measure the efficacy of an interdisciplinary $\mathrm{CP}$ rehabilitation program [51]. By combining different assessment methods such as activity analysis, occupational interviews, observations, and 
standardized functional tests, occupational therapists are skilled to observe and understand the interaction between multiple personal, environmental, and occupational factors that explain the gap between what a person living with $\mathrm{CP}$ wants and needs to do and their level of participation $[35,93]$.

4.4. Interventions Methods. On top of having tools and expertise to quantify and objectively measure occupational performance and engagement (functional performance), occupational therapists also are experts at restoring function through purposeful and meaningful occupations [94]. This intervention was supported by this scoping review which exposed that of the 30 different OT interventions in $\mathrm{CP}$ management, seventy-three percent of them related directly to the person, $20 \%$ pertained to activities and participation, and $7 \%$ addressed environmental factors. Interestingly, the two most frequently discussed interventions refer to an occupation-based intervention: pacing and graded activity (36.5\%) and activity (task) adaptation (32.7\%).

People with CP show lifestyle and work-related issues which suggest a need for interventions which consider the complex relationships between the person, environment, and occupations [95]. However, in the last few years, little research about the efficacy of OT interventions in $\mathrm{CP}$ management has been conducted despite explicit recommendations $[11,19]$. Considering evidence that engagement in occupation is essential for health and well-being, new studies in the field of OT will enforce the unique contribution of occupational therapists to the management of CP. Occupation-based interventions do exist; for instance, Simon and Collins [71] recently suggested that a specific OT intervention optimizes participation in integrated occupations and could contribute to $\mathrm{CP}$ management. Also of interest, for $\mathrm{CP}$ adults, could be training in Lifestyle Redesign ${ }^{\circledR}$ which is a manualized OT intervention grounded in occupational science research. This training technique focuses on facilitating client development of healthy self-care routines and habits to prevent and manage chronic conditions. According to these authors, this manualized intervention has demonstrated significant changes in occupational performance and satisfaction scores, physical and social functioning, role limitations due to physical and emotional problems, energy and fatigue, general health, and pain self-efficacy in adult with CP. Other studies of this kind are essential to expose to the health professional community research known to scientifically support OT practice interventions reflecting OT specificity in CP management.

4.5. Future Implications. According to Cronin and Mandich [88], occupational therapists need to be fluent in both the bottom-up and the top-down approaches and understand their strengths and weaknesses within different clinical situations. The bottom-up and the top-down approach to evaluation and to intervention are complementary and prioritized according to the needs of the client and clinical setting and considering the client's stage of rehabilitation and readiness to address specific types of problems [96]).
However, occupational therapists should take warrant that the historic tendency to relying too much on the bottom-up approach might in some cases forego or at least reduce the OT impact on participation. To promote a better understanding of the centrality of occupation, when choosing either a top-down or bottom-up approach, occupational therapists should seek to explicitly link their intervention to long-term outcomes linked to occupational performance and engagement or participation. This is a crucial challenge for occupational therapists especially if a bottom-up approach is privileged. By relentlessly reminding health professionals that OT focus is on occupation as a mean and an end, the profession will continue to strongly position itself as a valuable and distinctive contribution to adult $\mathrm{CP}$ management.

4.6. Study Strengths and Limitations. In this study, we meticulously followed the first five steps recommended to conduct a scoping review and explored a variety of sources to ensure that the most relevant documents were included. Covalidation of data charting and analyses also ensured that interpretation of the findings was valid. However, the inclusion of stage six, although optional, would have made it possible to provide opportunities for consumer and stakeholder involvement to suggest additional references and provide insights beyond those in the literature [26]. This has partly been addressed by a covalidation process that has been put in place within the research team and two collaborators. Also, despite an extensive search, some relevant documents may have been missed. Moreover, the quality of the publications included in this review was not critically appraised because this criterion is not one of the objectives of scoping reviews. Nonetheless, we are confident that the current study provides a clear picture of current knowledge and is a good starting point to orient future research and helps understanding and promoting OT in CP management knowing that the referral to an occupational therapist depends on other health care professionals' knowledge and understanding about OT [95].

\section{Conclusion}

In this scoping review, four themes linked to the current state of knowledge about OT in CP management emerged: (i) as an expert in enabling occupation, occupational therapists are particularly interested in how individuals living with $\mathrm{CP}$ can perform and engage in their daily occupations, (ii) the use of disciplinary models ensures a better emphasis on occupation as an end and as a mean throughout the entire OT treatment process, (iii) the top-down approach which is more in line with OT specific values and skills is complementary to the bottom-up approach, and iv) further studies about occupation-based interventions and their effectiveness are required to better address occupational issues which are facing adults living with $\mathrm{CP}$ and enrich the entire $\mathrm{OT}$ practice process by bringing forward its specific contribution to the optimization of the participation of people facing occupational challenges related to living with $\mathrm{CP}$ on a daily basis. 


\section{Conflicts of Interest}

The authors declare they have no conflicts of interest.

\section{Acknowledgments}

The authors thank librarian Kathy Rose for her contribution to the development of the research strategy. The authors also thank Annie Rochette and Carmen Moliner for their time shared and sound advice. This study was funded by the Faculty of Medicine and Health Sciences, Université de Sherbrooke.

\section{References}

[1] R.-D. Treede, W. Rief, A. Barke et al., "A classification of chronic pain for ICD-11,” Pain, vol. 156, no. 6, 2015.

[2] R. A. Elzahaf, O. A. Tashani, B. A. Unsworth, and M. I. Johnson, "The prevalence of chronic pain with an analysis of countries with a Human Development Index less than 0.9: a systematic review without meta-analysis," Current Medical Research and Opinion, vol. 28, no. 7, pp. 1221-1229, 2012.

[3] M. Duenas, B. Ojeda, A. Salazar, J. A. Mico, and I. Failde, "A review of chronic pain impact on patients, their social environment and the health care system," Journal of Pain Research, vol. 9, pp. 457-467, 2016.

[4] K. J. Reid, J. Harker, M. M. Bala et al., "Epidemiology of chronic non-cancer pain in Europe: narrative review of prevalence, pain treatments and pain impact," Current Medical Research and Opinion, vol. 27, no. 2, pp. 449-462, 2011.

[5] World Health Organization, World Health Organization Supports Global Effort to Relieve Chronic Pain, World Health Organization, Geneva, Switzerland, 2004, https://www.who. int/mediacentre/news/releases/2004/pr70/en/.

[6] E. Townsend and H. J. Polatajko, Enabling Occupation II: Advancing an Occupational Therapy Vision for Health, WellBeing and Justice Through Occupation, p. 494, CAOT publications ACE, Ottawa, Canada, 2007.

[7] A. Rochette, N. Korner-Bitensky, and M. Levasseur, "Optimal participation: a reflective look," Disability and Rehabilitation, vol. 28, no. 19, pp. 1231-1235, 2006.

[8] M. Larsson-Lund and A. Nyman, "Participation and occupation in occupational therapy models of practice: a discussion of possibilities and challenges," Scandinavian Journal of Occupational Therapy, vol. 24, no. 6, pp. 393-397, 2017.

[9] World Health Organization, How to Use the ICF: A Practical Manual for Using the International Classification of Functioning, Disability and Health (ICF), World Health Organization, Geneva, Switzerland, 2013.

[10] H. Hemmingsson and H. Jonsson, "An occupational perspective on the concept of participation in the international classification of functioning, disability and health-some critical remarks," American Journal of Occupational Therapy, vol. 59, no. 5, pp. 569-576, 2005.

[11] CAOT, Position Statement Pain Management and Occupational Therapy, Canadian Association of Occupational Therapist, Nepean, Canada, 2012.

[12] W. Hill, "The role of occupational therapy in pain management," Anaesthesia and Intensive Care Medicine, vol. 17, no. 9, pp. 451-453, 2016.

[13] G. S. Fisher, L. Emerson, C. Firpo, J. Ptak, J. Wonn, and G. Bartolacci, "Chronic pain and occupation: an exploration of the lived experience," American Journal of Occupational Therapy, vol. 61, no. 3, pp. 290-302, 2007.

[14] M. I. Hasenbring and J. A. Verbunt, "Fear-avoidance and endurance-related responses to pain: new models of behavior and their consequences for clinical practice," Clinical Journal of Pain, vol. 26, no. 9, pp. 747-753, 2010.

[15] M. I. Hasenbring, D. Hallner, and A. C. Rusu, "Fearavoidance- and endurance-related responses to pain: development and validation of the Avoidance-Endurance Questionnaire (AEQ)," European Journal of Pain, vol. 13, no. 6, pp. 620-628, 2009.

[16] N. E. Andrews, J. Strong, P. J. Meredith, K. Gordon, and K. S. Bagraith, "“It's very hard to change yourself": an exploration of overactivity in people with chronic pain using interpretative phenomenological analysis," Pain, vol. 156, no. 7, pp. 1215-1231, 2015.

[17] N. E. Andrews, P. J. Meredith, J. Strong, and G. F. Donohue, "Adult attachment and approaches to activity engagement in chronic pain," Pain Research and Management, vol. 19, no. 6, pp. 317-327, 2014.

[18] J. Strong, Chronic Pain: the Occupational Therapist's Perspective, Churchill Livingston, Edinburgh, UK, 1996.

[19] K. Robinson, N. Kennedy, and D. Harmon, "Is occupational therapy adequately meeting the needs of people with chronic pain?," American Journal of Occupational Therapy, vol. 65, no. 1, pp. 106-113, 2011.

[20] Å. Skjutar, M.-L. Schult, K. Christensson, and M. Müllersdorf, "Indicators of need for occupational therapy in patients with chronic pain: occupational therapists' focus groups," Occupational Therapy International, vol. 17, no. 2, pp. 93-103, 2009.

[21] J. Silvestri, "Effects of chronic shoulder pain on quality of life and occupational engagement in the population with chronic spinal cord injury: preparing for the best outcomes with occupational therapy," Disability and Rehabilitation, vol. 39, no. 1, pp. 82-90, 2017.

[22] G. Kielhofner, Model of Human Occupation: Theory and Application, Lippincott Williams \& Wilkins, Philadelphia, PA, USA, 2008.

[23] M. Hesselstrand, K. Samuelsson, and G. Liedberg, "Occupational therapy interventions in chronic pain-a systematic review," Occupational Therapy International, vol. 22, no. 4, pp. 183-194, 2015.

[24] H. L. Colquhoun, T. S. Jesus, K. K. O’Brien et al., "Study protocol for a scoping review on rehabilitation scoping reviews," Clinical Rehabilitation, vol. 31, no. 9, pp. 1249-1256, 2017.

[25] M. Saini and A. Shlonsky, Systematic Synthesis of Qualitative Research, Oxford University Press, Cary, NC, USA, 2012.

[26] D. Levac, H. Colquhoun, and K. K. O’Brien, “Scoping studies: advancing the methodology," Implementation Science, vol. 5, no. 1, 2010.

[27] H. Arksey and L. O’Malley, “Scoping studies: towards a methodological framework," International Journal of Social Research Methodology, vol. 8, no. 1, pp. 19-32, 2005.

[28] M. D. J. Peters, C. M. Godfrey, H. Khalil, P. McInerney, D. Parker, and C. B. Soares, "Guidance for conducting systematic scoping reviews," International Journal of EvidenceBased Healthcare, vol. 13, no. 3, pp. 141-146, 2015.

[29] P. Paillé and A. Mucchielli, L'analyse Qualitative en Sciences Humaines et Sociales, Armand Colin, Paris, France, 2nd edition, 2008.

[30] B. Aegler and T. Satink, "Performing occupations under pain: the experience of persons with chronic pain," Scandinavian Journal of Occupational Therapy, vol. 16, no. 1, pp. 49-56, 2009. 
[31] J. Artner, C. Kurz, and L. Reichel, "Intensive interdisciplinary outpatient pain management program for chronic back pain: a pilot study," Journal of Pain Research, vol. 5, pp. 209-216, 2012.

[32] S. Ashby, M. Fitzgerald, and S. Raine, "The impact of chronic low back pain on leisure participation: implications for occupational therapy," British Journal of Occupational Therapy, vol. 75, no. 11, pp. 503-508, 2012.

[33] D. Bosy, D. Etlin, D. Corey, and J. W. Lee, "An interdisciplinary pain rehabilitation programme: description and evaluation of outcomes," Physiotherapy Canada, vol. 62, no. 4, pp. 316-326, 2010.

[34] I. Caby, N. Olivier, F. Janik, J. Vanvelcenaher, and P. Pelayo, "A controlled and retrospective study of 144 chronic low back pain patients to evaluate the effectiveness of an intensive functional restoration program in France," Healthcare, vol. 4, no. 2, p. 23, 2016.

[35] T. Cammalleri, Understanding the Relationships Between the Roman Catholic Faith, Pain Experience and Everyday Life, Dalhousie University, Halifax, Canada, 2008.

[36] C. Demoulin, S. Grosdent, L. Capron et al., "Effectiveness of a semi-intensive multidisciplinary outpatient rehabilitation program in chronic low back pain," Joint Bone Spine, vol. 77, no. 1, pp. 58-63, 2010.

[37] P. L. Dobkin, A. Liu, M. Abrahamowicz et al., "Predictors of disability and pain six months after the end of treatment for fibromyalgia," Clinical Journal of Pain, vol. 26, no. 1, pp. 23-29, 2010.

[38] G. S. Fisher, C. Beckwith-Cohen, S. Edwards, C. Howe, L. Smith, and T. Sugrue, "Developing and field testing the pain and functional performance assessment for individuals with chronic pain," Journal of Musculoskeletal Pain, vol. 17, no. 3, pp. 258-270, 2009.

[39] J.-P. Gallice, D. Kupper, D. Rentsch, V. Barthassat, C. Cedraschi, and S. Genevay, "Multidisciplinary programs and chronic low back pain: concepts and practical aspects. Part 2: in practice," Kinésithérapie, la Revue, vol. 10, no. 102, pp. 40-44, 2010.

[40] R. J. Gatchel, A. Dougall, J. Robert, Schultz, and Z. Izabela, "Psychosocial and psychiatric sequelae of chronic musculoskeletal pain and disability disorders (Chap 12)," in Handbook of Musculoskeletal Pain and Disability Disorders in the Work Place, R. Gatchel, Ed., pp. 219-234, Springer, New York, NY, USA, 2014.

[41] B. Lippe, P. Polantin, J. Robert, Schultz, and Z. Izabela, “The interdisciplinary treatment approach for chronic pain management: the key components for success (Chap 20)," in Handbook of Musculoskeletal Pain and Disability Disorders in the Work Place, R. Gatchel, Ed., pp. 365-378, Springer, New York, NY, USA, 2014.

[42] K. Chapman, R. Lisson, B. Haynes, J. Robert, Schultz, and Z. Izabela, "Vocational assessment and training for patients with chronic occupational musculoskeletal disorders (Chap 25)," in Handbook of Musculoskeletal Pain and Disability Disorders in the Work Place, R. Gatchel, Ed., pp. 453-470, Springer, New York, NY, USA, 2014.

[43] J. Gonzalez, M. del M. del Teso Rubio, C. N. Waliño Paniagua, J. J. Criado-Alvarez, and J. Sanchez Holgado, "Symptomatic pain and fibromyalgia treatment through multidisciplinary approach for primary care," Reumatología Clínica (English Edition), vol. 11, no. 1, pp. 22-26, 2015.

[44] R. N. Harden, M. Swan, and J. Barthel, "Treatment of complex regional pain syndrome," Clinical Journal of Pain, vol. 22, no. 5, pp. 420-424, 2006.
[45] R. N. Harden, A. L. Oaklander, A. W. Burton et al., "Complex regional pain syndrome: practical diagnostic and treatment guidelines, 4th edition," Pain Medicine, vol. 14, no. 2, pp. 180-229, 2013.

[46] M. E. Hardison and S. C. Roll, "Mindfulness interventions in physical rehabilitation: a scoping review," American Journal of Occupational Therapy, vol. 70, no. 3, 2016.

[47] M. Jarrar, The Effects of Mirror Therapy on Upper Extremity Pain and Function in Patients with Complex Regional Pain Syndrome: Systematic Review and Case Study, State University of New York, Buffalo, NY, USA, 2014.

[48] C. Kallhed and L. Mårtensson, "Strategies to manage activities in everyday life after a pain rehabilitation program," Scandinavian Journal of Occupational Therapy, vol. 25, no. 2, pp. 145-152, 2018.

[49] R. Keponen and G. Kielhofner, "Occupation and meaning in the lives of women with chronic pain," Scandinavian Journal of Occupational Therapy, vol. 13, no. 4, pp. 211-220, 2006.

[50] S. A. King, "Chronic pain management: non Pharmacologic therapies," Consultant, vol. 53, no. 3, p. 275, 2013.

[51] S. Kurklinsky, R. B. Perez, E. R. Lacayo, and C. D. Sletten, "The efficacy of interdisciplinary rehabilitation for improving function in people with chronic pain," Pain Research and Treatment, vol. 2016, Article ID 7217684, 6 pages, 2016.

[52] M. Linden, S. Scherbe, and B. Cicholas, "Randomized controlled trial on the effectiveness of cognitive behavior group therapy in chronic back pain patients," Journal of Back and Musculoskeletal Rehabilitation, vol. 27, no. 4, pp. 563-568, 2014.

[53] M. Mathews, "Multimodal treatment of pain," Neurosurgery Clinics of North America, vol. 25, no. 4, pp. 803-808, 2014.

[54] G. L. McCormack and J. Gupta, "Using complementary," OT Practice, vol. 12, no. 13, pp. 16-20, 2007.

[55] A. McLean, "Supporting individuals with migraine in the workplace," Work, vol. 34, no. 1, pp. 123-127, 2009.

[56] A. McLean, K. Coutts, and W. J. Becker, "Pacing as a treatment modality in migraine and tension-type headache," Disability and Rehabilitation, vol. 34, no. 7, pp. 611-618, 2012.

[57] V. D. Miles, Treating Persistent Pain: A Contemporary Development of a Multidisciplinary Chronic Pain Program, Vol. 225, 2011.

[58] M. G. Nieuwenhuizen, S. de Groot, T. W. J. Janssen, L. C. C. van der Maas, and H. Beckerman, "Canadian occupational performance measure performance scale: validity and responsiveness in chronic pain," Journal of Rehabilitation Research and Development, vol. 51, no. 5, pp. 727-746, 2014.

[59] S. Paquette, "Return to work with chronic low back pain: using an evidence-based approach along with the occupational therapy framework," Work: Journal of Prevention, Assessment and Rehabilitation, vol. 31, no. 1, pp. 63-71, 2008.

[60] M. Pérez de Heredia-Torres, E. Huertas-Hoyas, N. MáximoBocanegra, D. Palacios-Ceña, and C. Fernández-De-LasPeñas, "Cognitive performance in women with fibromyalgia: a case-control study," Australian Occupational Therapy Journal, vol. 63, no. 5, pp. 329-337, 2016.

[61] G. Perneros and H. Tropp, "Development, validity, and reliability of the assessment of Pain and Occupational Performance (POP): a new instrument using two dimensions in the investigation of disability in back pain," Spine Journal, vol. 9, no. 6, pp. 486-498, 2009.

[62] G. Perneros, H. Tropp, and J. Sandqvist, "Evaluation of occupational performance and pain intensity: before and after back surgery and rehabilitation," Scandinavian Journal of Occupational Therapy, vol. 21, no. 1, pp. 69-81, 2014. 
[63] E. Persson, J. Lexell, M. Rivano-Fischer, and M. Eklund, "Everyday occupational problems perceived by participants in a pain rehabilitation programme," Scandinavian Journal of Occupational Therapy, vol. 20, no. 4, pp. 306-314, 2013.

[64] J. L. Poole and P. Siegel, "Effectiveness of occupational therapy interventions for adults with fibromyalgia: a systematic review," American Journal of Occupational Therapy, vol. 71, no. 1, article 7101180040p1, 2017.

[65] K. Prefontaine and A. Rochette, "A literature review on chronic pain: the daily overcoming of a complex problem," British Journal of Occupational Therapy, vol. 76, no. 6, pp. 280-286, 2013.

[66] M. J. Ravenek, I. D. Hughes, N. Ivanovich et al., “A systematic review of multidisciplinary outcomes in the management of chronic low back pain," Work: Journal of Prevention, Assessment and Rehabilitation, vol. 35, no. 3, pp. 349-367, 2010.

[67] K. Robinson, N. Kennedy, and D. Harmon, "Review of occupational therapy for people with chronic pain," Australian Occupational Therapy Journal, vol. 58, no. 2, pp. 74-81, 2011.

[68] L. Rome, "The place of occupational therapy in rehabilitation strategies of complex regional pain syndrome: comparative study of 60 cases," Hand Surgery and Rehabilitation, vol. 35, no. 5, pp. 355-362, 2016.

[69] M. Salgueiro, X. Basogain, A. Collado et al., "An artificial neural network approach for predicting functional outcome in fibromyalgia syndrome after multidisciplinary pain program," Pain Medicine, vol. 14, no. 10, pp. 1450-1460, 2013.

[70] A. U. Simon and C. E. R. Collins, "Lifestyle Redesign ${ }^{\circledR}$ for chronic pain management: a retrospective clinical efficacy study," American Journal of Occupational Therapy, vol. 71, no. 4, article 7104190040p1, 2017.

[71] S. Stanos, "Focused review of interdisciplinary pain rehabilitation programs for chronic pain management," Current Pain and Headache Reports, vol. 16, no. 2, pp. 147-152, 2012.

[72] D. E. Stewart, B. Jakubowicz, K. Beard, G. Cyphers, and D. V. Turner, "Revisiting chronic pain in the life care plan," Journal of Life Care Planning, vol. 14, no. 2, pp. 39-45, 2016.

[73] D. Q. H. Tran, S. Duong, P. Bertini, and R. J. Finlayson, "Treatment of complex regional pain syndrome: a review of the evidence," Canadian Journal of Anesthesia, vol. 57, no. 2, pp. 149-166, 2010.

[74] H. van Huet, E. Innes, and R. Stancliffe, "Occupational therapists perspectives of factors influencing chronic pain management," Australian Occupational Therapy Journal, vol. 60, no. 1, pp. 56-65, 2013.

[75] C. Von Bülow, K. Amris, K. La Cour, B. Danneskiold-Samsøe, and E. E. Wæhrens, "Ineffective ADL skills in women with fibromyalgia: a cross-sectional study," Scandinavian Journal of Occupational Therapy, vol. 23, no. 5, pp. 391-397, 2016.

[76] E. Townsend, Enabling Occupation: an Occupational Therapy Perspective, p. 210, CAOT publications, Ottawa, Canada, 1997.

[77] H. J. Polatajko, E. Townsend, and J. Craik, "Canadian model of occupational performance and engagement (CMOP-E)," in Enabling Occupation II: Advancing an Occupational Therapy Vision of Health, Well-being, \& Justice through Occupation, CAOT Publications ACE, Ottawa, Canada, 2007.

[78] M. N. Ikiugu, S. Smallfield, and C. Condit, "A framework for combining theoretical conceptual practice models in occupational therapy practice," Canadian Journal of Occupational Therapy, vol. 76, no. 3, pp. 162-170, 2009.

[79] M. A. McColl and M. Law, "Interventions affecting self-care, productivity, and leisure among adults: a scoping review," OTJR: Occupation, Participation and Health, vol. 33, no. 2, pp. 110-119, 2013.
[80] I. Caby, N. Olivier, F. Mendelek, R. B. Kheir, J. Vanvelcenaher, and P. Pelayo, "Restauration fonctionnelle du rachis: effet du niveau initial de douleur sur les performances des sujets lombalgiques chroniques. $=$ Functional restoration of the spine: effect of initial pain level on the performance of subjects with chronic low back pain," Pain Research and Management, vol. 19, no. 5, pp. e133-e138, 2014.

[81] T. Brown and C.-W. Chien, "Top-down or bottom-up occupational therapy assessment: which way do we go?," British Journal of Occupational Therapy, vol. 73, no. 3, p. 95, 2010.

[82] World Health Organization, International Classification of Functioning, Disability and Health: ICF, World Health Organization, Geneva, Switzerland, 2001.

[83] G. Kielhofner, Conceptual Foundations of Occupational Therapy Practice, F. A. Davis, Duxbury, VT, USA, 2009.

[84] S. Burley, A. Di Tommaso, R. Cox, and M. Molineux, "An occupational perspective in hand therapy: a scoping review," British Journal of Occupational Therapy, vol. 81, no. 6, pp. 299-318, 2018.

[85] S. R. Wong and G. Fisher, "Comparing and using occupationfocused models," Occupational Therapy In Health Care, vol. 29, no. 3, pp. 297-315, 2015.

[86] C. Benaim, B. Léger, P. Vuistiner, and F. Luthi, "Validation of the French version of the "patterns of activity measure" in patients with chronic musculoskeletal pain," Pain Research and Management, vol. 2017, Article ID 6570394, 7 pages, 2017.

[87] S. Stewart, "The use of standardised and non-standardised assessments in a social services setting: implications for practice," British Journal of Occupational Therapy, vol. 62, no. 9, pp. 417-423, 1999.

[88] A. Cronin and M. Mandich, Human Development and Performance, Cengage Learning, Boston, USA, 2nd edition, 2016.

[89] N. Forget and J. Higgins, "Comparison of generic patientreported outcome measures used with upper extremity musculoskeletal disorders: linking process using the International Classification of Functioning, Disability, and Health (ICF)," Journal of Rehabilitation Medicine, vol. 46, no. 4, pp. 327-334, 2014.

[90] R. H. Dworkin, D. C. Turk, J. T. Farrar et al., "Core outcome measures for chronic pain clinical trials: IMMPACT recommendations," Pain, vol. 113, no. 1, pp. 9-19, 2005.

[91] G. Kielhofner, A User's Manual for the Occupational Performance History Interview (Version 2.1), OPHI-II. Chigago, Chicago, IL, USA, 2004.

[92] M. Law, S. Baptiste, A. Carswell, M. McColl, H. J. Polatajko, and N. Pollock, La mesure canadienne du rendement occupationnel, CAOT publications ACE, Ottawa, Canada, 3rd edition, 2000.

[93] R. J. Gatchel and I. Z. Schultz, "Handbook of Musculoskeletal Pain and Disability Disorders in the Workplace," in Handbooks in Health, Work, and Disability, Springer New York, New York, NY, USA, 2014, https://link.springer.com/10.1007/ 978-1-4939-0612-3.

[94] B. M. Doucet, "Quantifying function: status critical," American Journal of Occupational Therapy, vol. 68, no. 2, pp. 123-126, 2014.

[95] M. Müllersdorf and I. Söderback, "Occupational therapists' assessments of adults with long-term pain: the Swedish experience," Occupational Therapy International, vol. 9, no. 1, pp. 1-23, 2002.

[96] B. M. Doucet and S. A. Gutman, "Quantifying function: the rest of the measurement story," American Journal of Occupational Therapy, vol. 67, no. 1, pp. 7-9, 2013. 


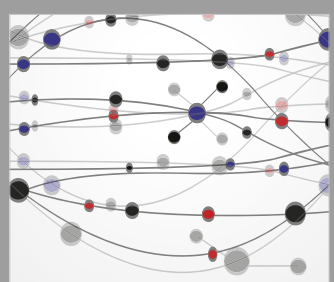

The Scientific World Journal
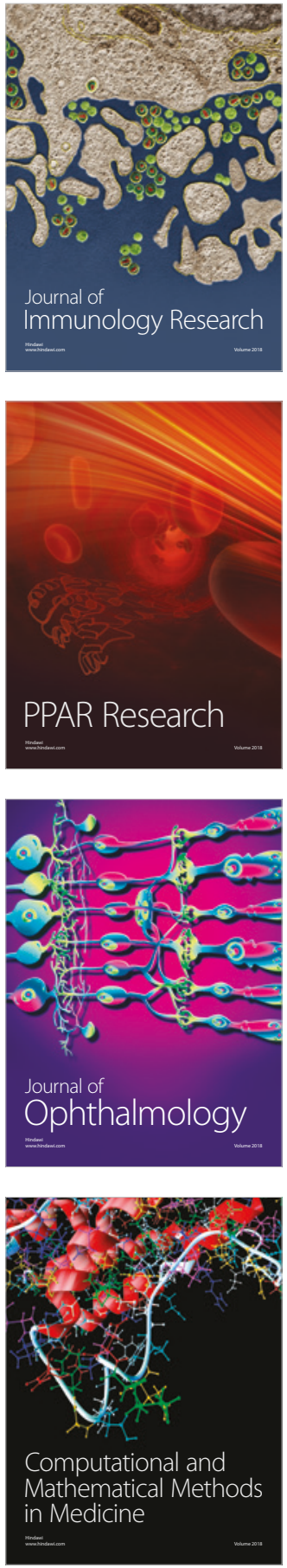

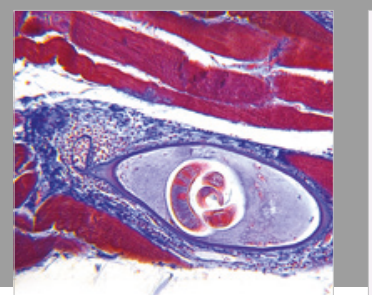

Gastroenterology Research and Practice

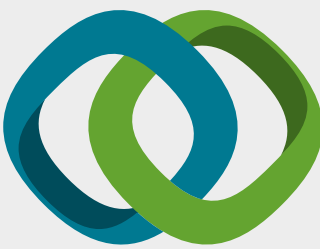

\section{Hindawi}

Submit your manuscripts at

www.hindawi.com
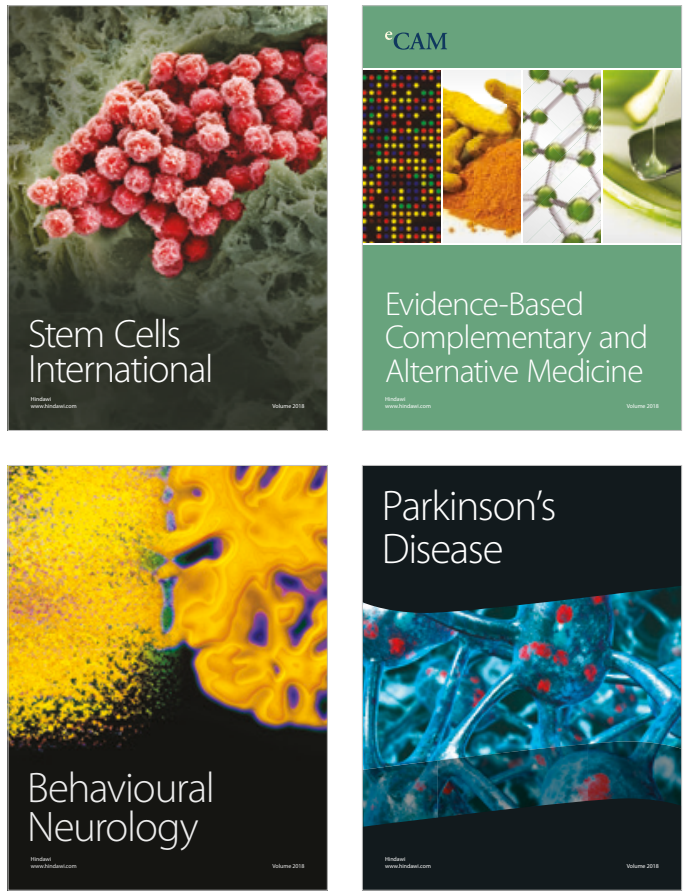

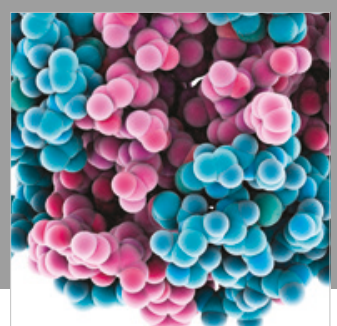

ournal of

Diabetes Research

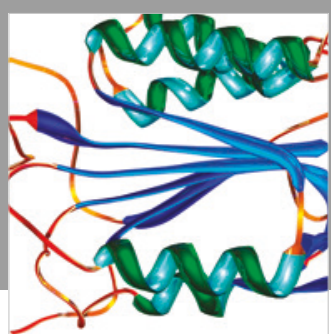

Disease Markers
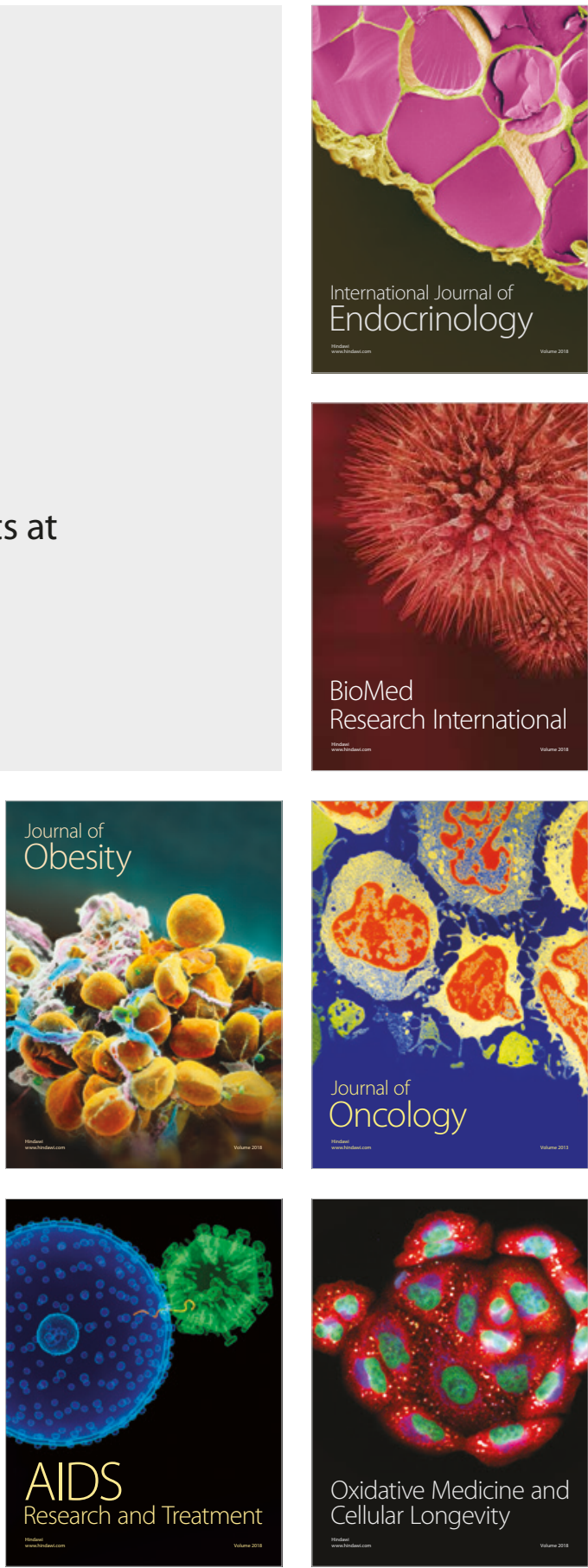